US Army Corps

of Engineers

Waterways Experiment

Station

\title{
Monitoring of East Breakwater Rehabilitation at Cleveland Harbor, Ohio
}

by Joan Pope, Robert R. Bottin, Jr. Coastal Engineering Research Center

Darlene Rowen

U.S. Army Engineer District, Buffalo

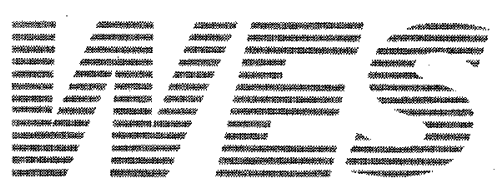

Approved For Public Release; Distribution Is Unlimited 


\section{Monitoring of East Breakwater Rehabilitation at Cleveland Harbor, Ohio}

by Joan Pope, Robert R. Bottin, Jr.

Coastal Engineering Research Center

U.S. Army Corps of Engineers

Waterways Experiment Station

3909 Halls Ferry Road

Vicksburg, MS 39180-6199

Darlene Rowen

U.S. Army Engineer District, Buffalo

1776 Niagara Street

Buffalo, NY 14207-3199

Final report

Approved for public release; distribution is unlimited 


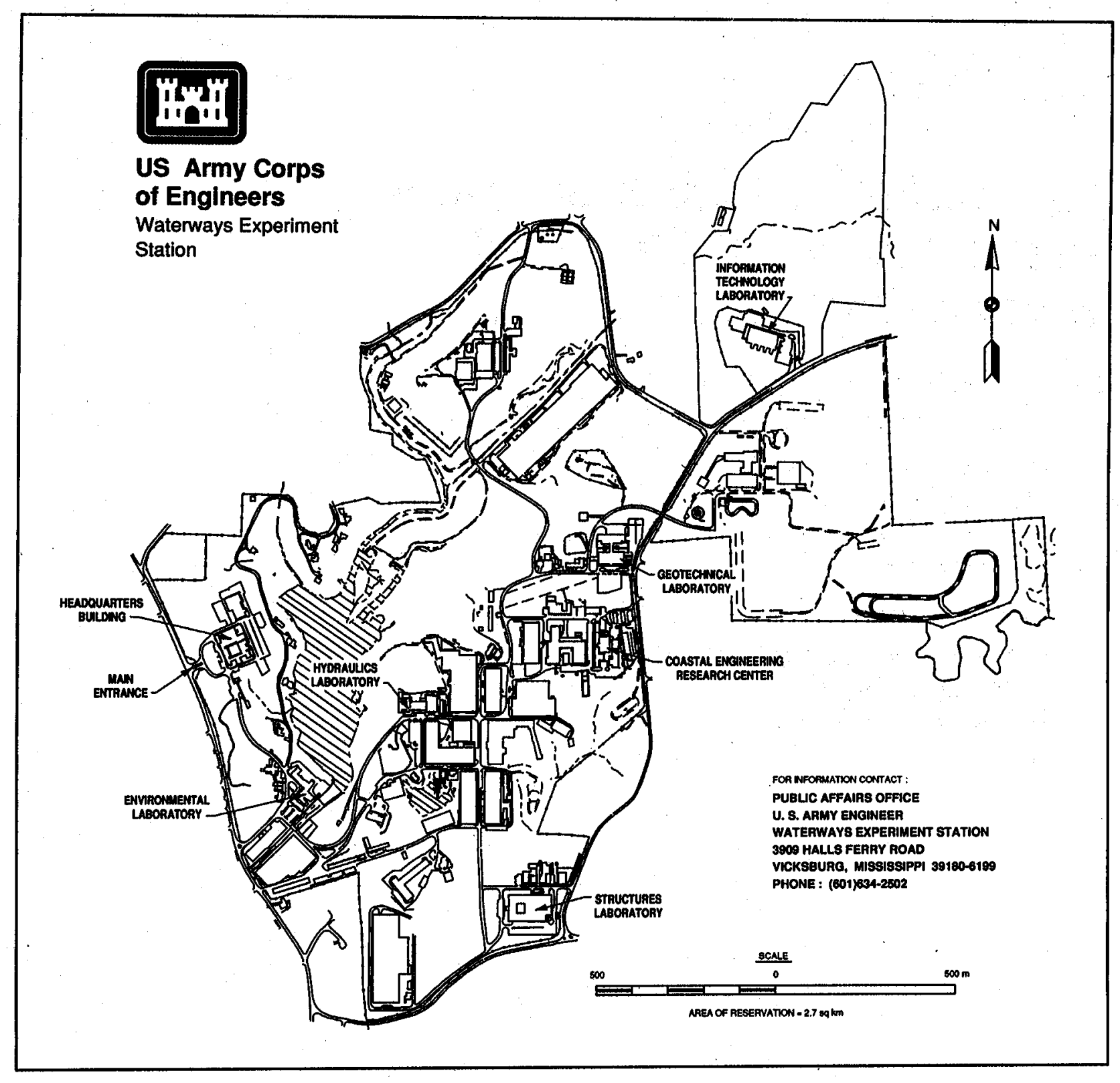

Waterways Experiment Station Cataloging-in-Publication Data

Pope, Joan.

Monitoring of east breakwater rehabilitation at Cleveland Harbor Ohio / by Joan Pope, Robert R. Bottin, Jr., Coastal Engineering Research Center, Darlene Rowen ; prepared for U.S. Army Corps of Engineers.

56 p. : ill. ; $28 \mathrm{~cm}$. - (Miscellaneous paper ; CERC-93-5) Includes bibliographical references.

1. Breakwaters - Ohio - Cleveland Harbor. 2. Harbors Ohio - Cleveland. 3. Hydraulic structures - Protection. 4.

Embankments - Maintenance and repair. I. Bottin, Robert R. II.

Rowen, Darlene D. III. United States. Army. Corps of Engineers. IV. Coastal Engineering Research Center (U.S.) V. U.S. Army Engineer Waterways Experiment Station. VI. Title. VII. Series: Miscellaneous paper (U.S. Army Engineer Waterways Experiment Station) ; CERC-93-5.

TA7 W34m no.CERC-93-5 


\section{Contents}

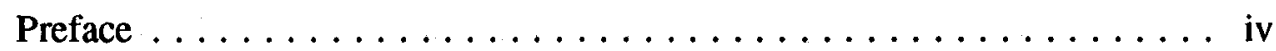

Conversion Factors, Non-SI to SI Units of Measurement $\ldots \ldots \ldots \ldots \ldots v$

1 -Introduction $\ldots \ldots \ldots \ldots \ldots \ldots \ldots \ldots \ldots \ldots$

Project Location and History $\ldots \ldots \ldots \ldots \ldots \ldots \ldots \ldots \ldots$

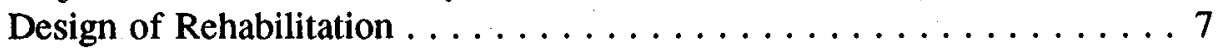

History of Dolos Use . . . . . . . . . . . . . . . . . . 11

Monitoring Completed Coastal Projects Program $\ldots \ldots \ldots \ldots \ldots$

2 -Monitoring Program $\ldots \ldots \ldots \ldots \ldots \ldots \ldots \ldots \ldots \ldots \ldots$

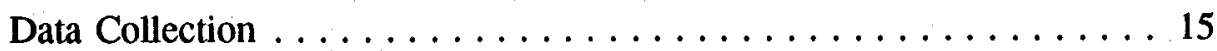

Monitoring Results $\ldots \ldots \ldots \ldots \ldots \ldots \ldots \ldots \ldots \ldots \ldots$

3-Related Studies and Post-Monitoring Activity . . . . . . . . 40

Maintenance Study . . . . . . . . . . . . . . 40

Two-Dimensional Model Study . . . . . . . . . . . . . 41

Post-Monitoring Rehabilitation $\ldots \ldots \ldots \ldots \ldots \ldots \ldots \ldots \ldots \ldots$

4 -Conclusions and Recommendations $\ldots \ldots \ldots \ldots \ldots$

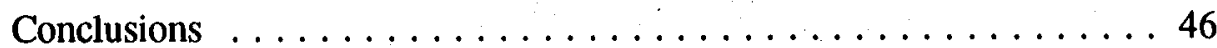

Recommendations ....................47

References $\ldots \ldots \ldots \ldots \ldots \ldots \ldots \ldots \ldots \ldots \ldots \ldots \ldots . \ldots \ldots$ 


\section{Preface}

Funding for the study reported herein was provided through the Monitoring Completed Coastal Projects (MCCP) Program. The program entails intense monitoring of selected Civil Works coastal projects to gather information that can be used in improving project purpose attainment, design procedures, construction methods, and operation and maintenance techniques. Overall program management for MCCP is accomplished by the Hydraulic Design Section of Headquarters, U.S. Army Corps of Engineers (HQUSACE). The Coastal Engineering Research Center (CERC), U.S. Army Engineer Waterways Experiment Station (WES), is responsible for technical and data management and support for HQUSACE review and technology transfer. Technical Monitors for the MCCP Program are Messis. John H. Lockhart, Jr., John G. Housley, and Barry W. Holliday. The Program Manager is Ms. Carolyn M. Holmes, CERC.

This report was prepared by Mr. Robert R. Bottin, Jr., Wave Processes Branch, Wave Dynamics Division, CERC, Ms. Joan Pope, Chief, Coastal Structures and Evaluation Branch, CERC, and Ms. Darlene Rowen, formerly of the U.S. Army Engineer District, Buffalo (CENCB), under the direct guidance of Mr. Thomas W. Richardson, Chief, Engineering Development Division, CERC, and the general supervision of Dr. James R. Houston and Mr. Charles C. Calhoun, Jr., Director and Assistant Director, CERC. Mr. Denton Clark, CENCB, supervised the Buffalo District's portion of the project. This report was typed by Ms. Karen R. Wood, CERC.

Dr. Robert W. Whalin was Director of WES. At the time of publication of this report, COL Leonard G. Hassell, EN, was Commander. 


\section{Conversion Factors, Non-SI to SI Units of Measurement}

Non-SI units of measurement used in this report can be converted to SI (metric) units as follows:

\begin{tabular}{||l|l|l||}
\hline \multicolumn{1}{|c|}{ Multiply } & \multicolumn{1}{c|}{ By } & \multicolumn{1}{c|}{ To Obtain } \\
\hline acres & 4046.856 & square meters \\
\hline degrees (angle) & 0.01745329 & radians \\
\hline feet & 0.3048 & meters \\
\hline inches & 2.54 & centimeters \\
\hline miles (U.S. statute) & 1.609344 & kilometers \\
\hline pounds (mass) & 0.4535924 & kilograms \\
\hline pounds (force) per square inch & 703.1 & kilograms/square meter \\
\hline tons (2,000 pounds, mass) & 907.1847 & kilograms \\
\hline
\end{tabular}




\section{Introduction}

\section{Project Location and History}

Cleveland Harbor is located on the southern shore of Lake Erie, 96 miles $^{1}$ east of Toledo, Ohio, and 176 miles west of Buffalo, New York (Figure 1). The harbor is situated at the mouth of the Cuyahoga River. It comprises approximately 1,300 acres and extends for a distance of about $25,000 \mathrm{ft}$ parallel to the shore (U.S. Army Engineer District (USAED), Buffalo 1976). Cleveland Harbor is protected by a breakwater system, which is over $30,000 \mathrm{ft}$ in aggregate length. There are two harbor entrances connecting the harbor with Lake Erie. The west entrance is directly lakeward of the Cuyahoga River mouth and the east entrance is at the eastern end of the east breakwater. Also, shallow-draft and recreational vessels can enter the harbor through a narrow opening in the west breakwater, which connects to Edgewater Marina (located adjacent to the west end of Cleveland Harbor). Aerial photos showing the layout of Cleveland Harbor are presented in Figures 2 and 3.

Cleveland Harbor accommodates the waterborne movement of bulk and general cargo to and from the city of Cleveland, the largest city in Ohio, and one of the major commerce ports in the Great Lakes system. The harbor also serves developments within Cleveland and throughout industrial and commercial portions of the state of Ohio and adjacent states. Vessel movements of bulk iron ore, stone, sand and gravel, and salt represent over 90 percent of the waterborne commerce. Forecasts indicate that these commodity movements will increase in the future and will continue to be the dominant portion of waterborne commerce at Cleveland.

The Cleveland Harbor breakwater provides protection to commercial shipping and allows vessels to maneuver and serve industry in the Cleveland Outer Harbor during stormy weather. The structural stability of the shoreline in the lee of the structures, which includes mooring areas, commerical developments, and an airport, is dependent upon the breakwater's ability to reduce the severity of wave action in the harbor. The breakwater also provides a harbor of refuge and boating area for small pleasure craft during storm wave

1 A table of factors for converting non-SI units of measurement to SI units is presented on page $v$. 


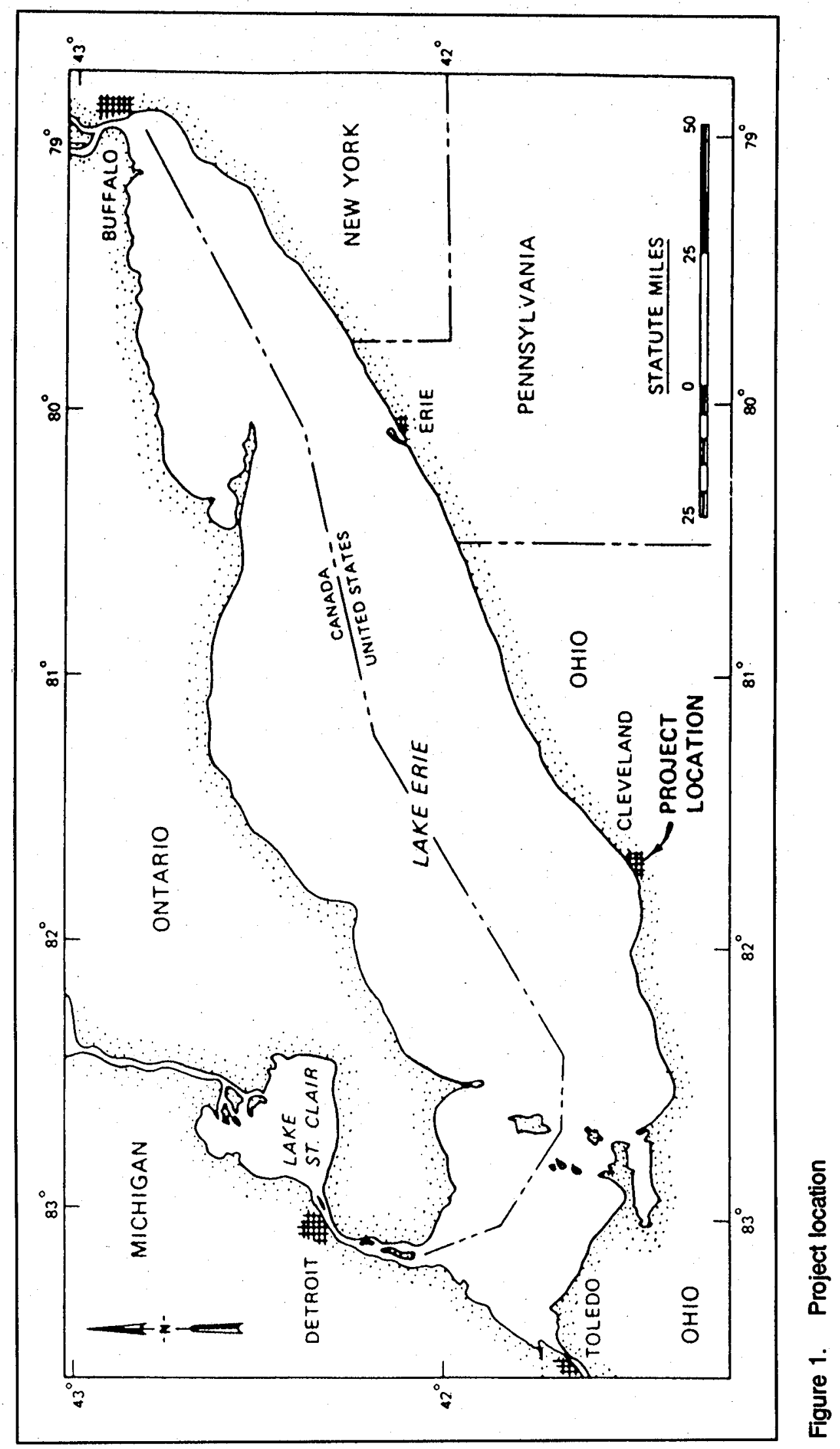




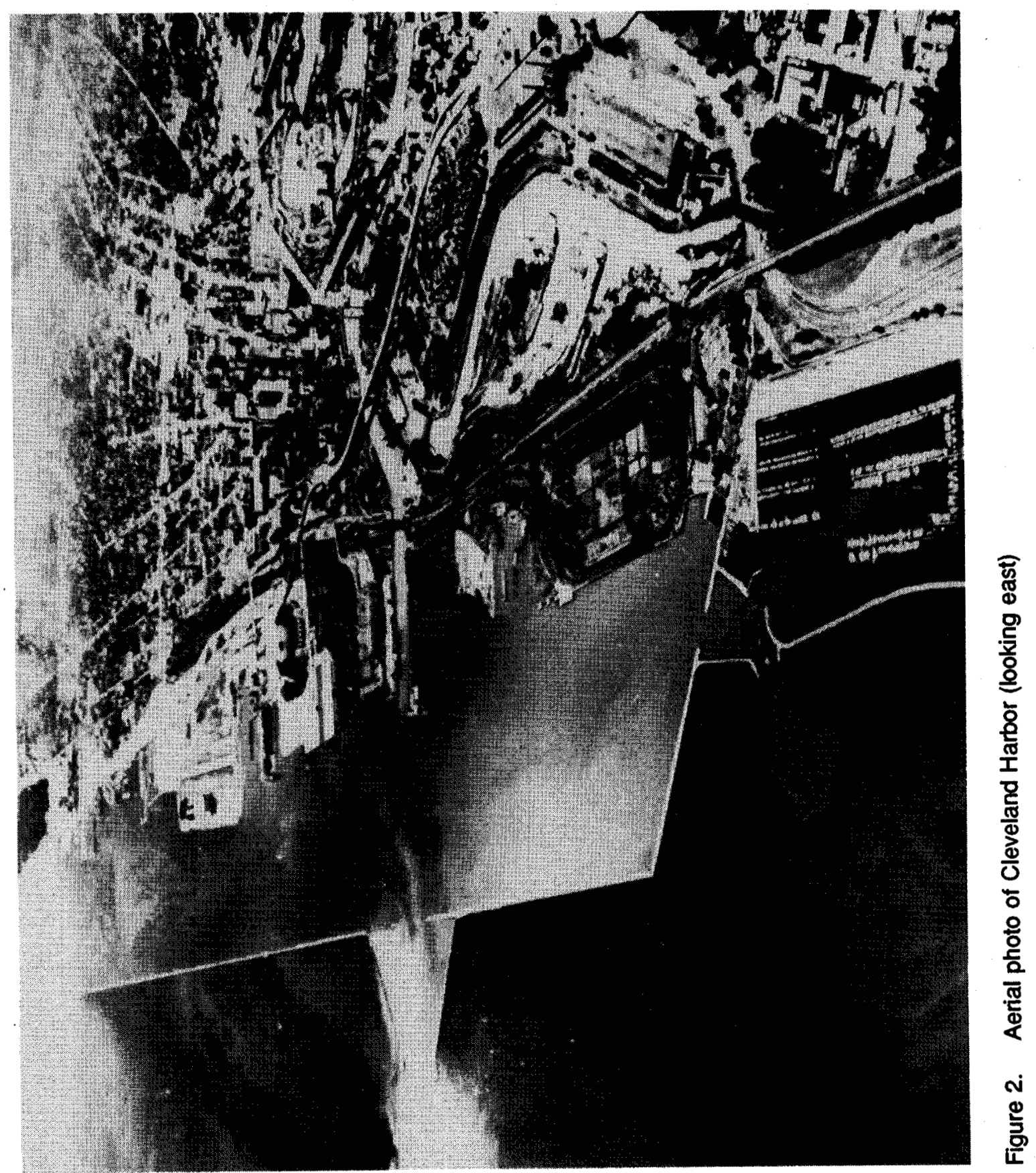




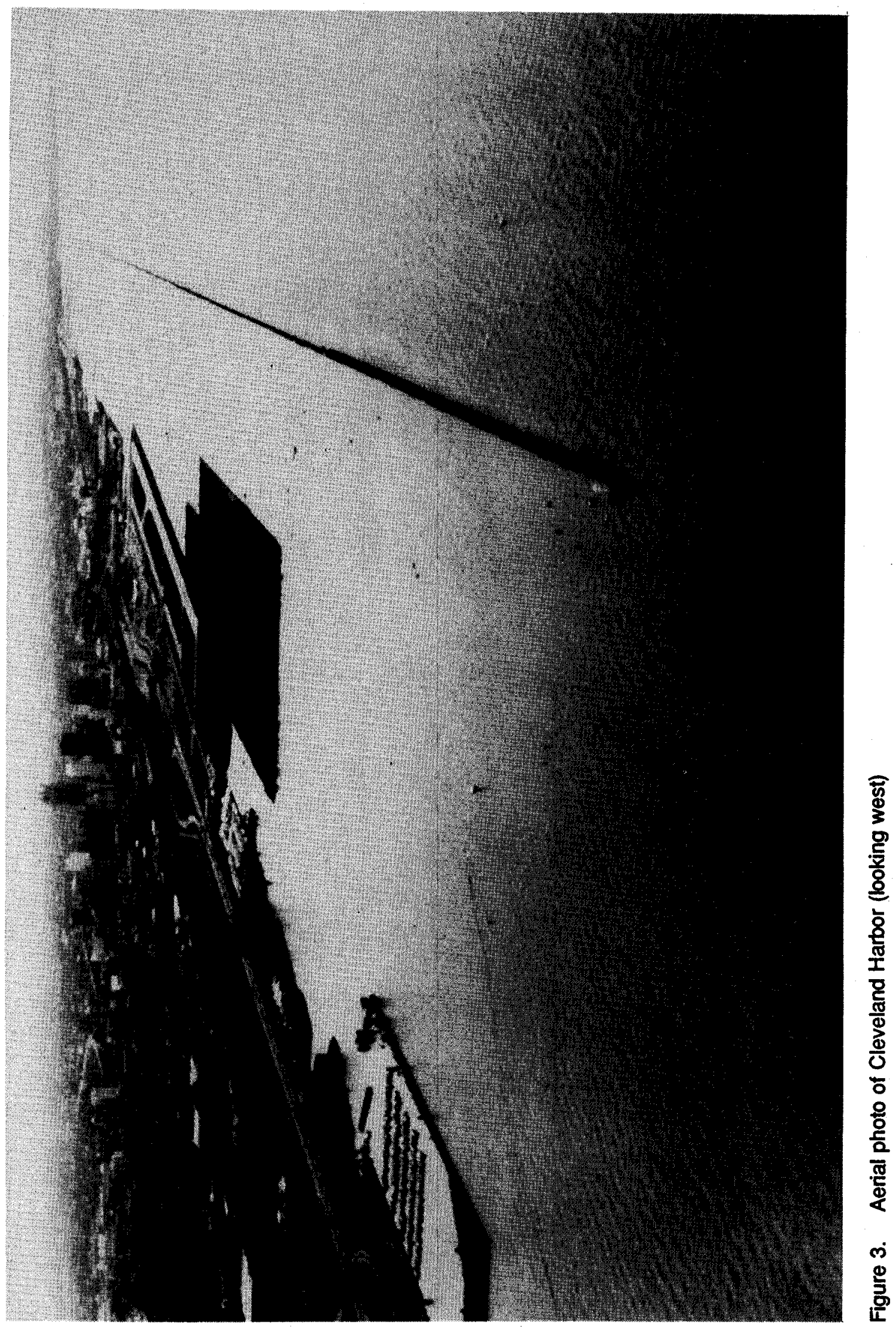


conditions. The large sheltered harbor basins are popular recreation boating areas that frequently host a range of waterborne activities.

The length of the existing east breakwater is $20,970 \mathrm{ft}$. The westerly 3,000-ft-long portion was constructed between 1887 and 1900, and was composed of a stone-filled timber crib structure with a concrete cap. During the period 1917-1926, a stone superstructure, including a sloping stone riprap, was placed on the lakeward site (Figure 4). The easterly $17,970 \mathrm{ft}$ was constructed between 1903 and 1915 and consisted of dumped core stone covered with large individually placed armor stone (Figure 5).

The project rehabilitation and study area involves the easterly $4,400 \mathrm{ft}$ of the east breakwater. The pre-rehabilitated breakwater within the project limits was of laid-up stone construction. Its core is composed of quarry run stone, of which not more than 50 percent weighs less than 1 ton. An armor layer consisting of 3- to 8-ton stone blocks covers the core. Additional stone weighing 10 to 14 tons has been placed over the years, on the existing cover layer and on the structure slope below the $-10 \mathrm{ft}$ elevation (el). ${ }^{1}$ The breakwater has a design crest el of $+10.3 \mathrm{ft}$ and a crest width of $10 \mathrm{ft}$. The side slopes on both the lake and harbor sides were constructed to $1 \mathrm{~V}: 1.5 \mathrm{H}$ slopes. A U.S. Coast Guard lighthouse is located at the easterly end of the breakwater at its head. It was constructed on a 21 - by 21-ft square concrete footing. Depths on the lake side of the structure generally range between -30 and $-35 \mathrm{ft}$. Depths are shallower on the harbor side due to natural accretion of sediments within the harbor since construction.

The east breakwater has had an extensive repair history. Storm damage has caused the displacement of the laid-up cover stone, especially on the lake side, resulting in the consequent and continous unravelling of the breakwater slope in many areas. Some deterioration and loss of individual cover stone had also resulted in exposure of the underlayer core stone. Subsequent loss of core stone during storm conditions has aggravated deterioration of the structure and some sections have collapsed. The structure's integrity has been affected adversely in the zone from $-10 \mathrm{ft}$ to $+10.3 \mathrm{ft}$ (crest height). Most of the structure damage is on the lake side with eventual deformation to the harbor side of the structure in areas where timely repairs were not made.

Repairs to the structure were made by rebuilding the damaged portion above $-10 \mathrm{ft}$ in a manner similar to the original construction using 3- to 8-ton stone. Below $-10 \mathrm{ft}$, additional stone weighing between 10 tons and 14 tons was randomly placed on the existing cover stone to help provide a base for the upper slope. Repairs were made to the east breakwater in 1927, 1928, 1930, 1932-34, 1936-40, and 1946-78. All work was performed by U.S. Army Corps of Engineers derrick boats and personnel experienced in the unique and time-consuming method of stone placement. Quarried sandstone blocks, required as cover stone, and other stone material were procured through supply

1 All elevations cited herein are in feet referred to low-water datum (lwd), el $568.6 \mathrm{ft}$ above mean water level at Father Point, Quebec (International Great Lakes Dạtum, 1955). 


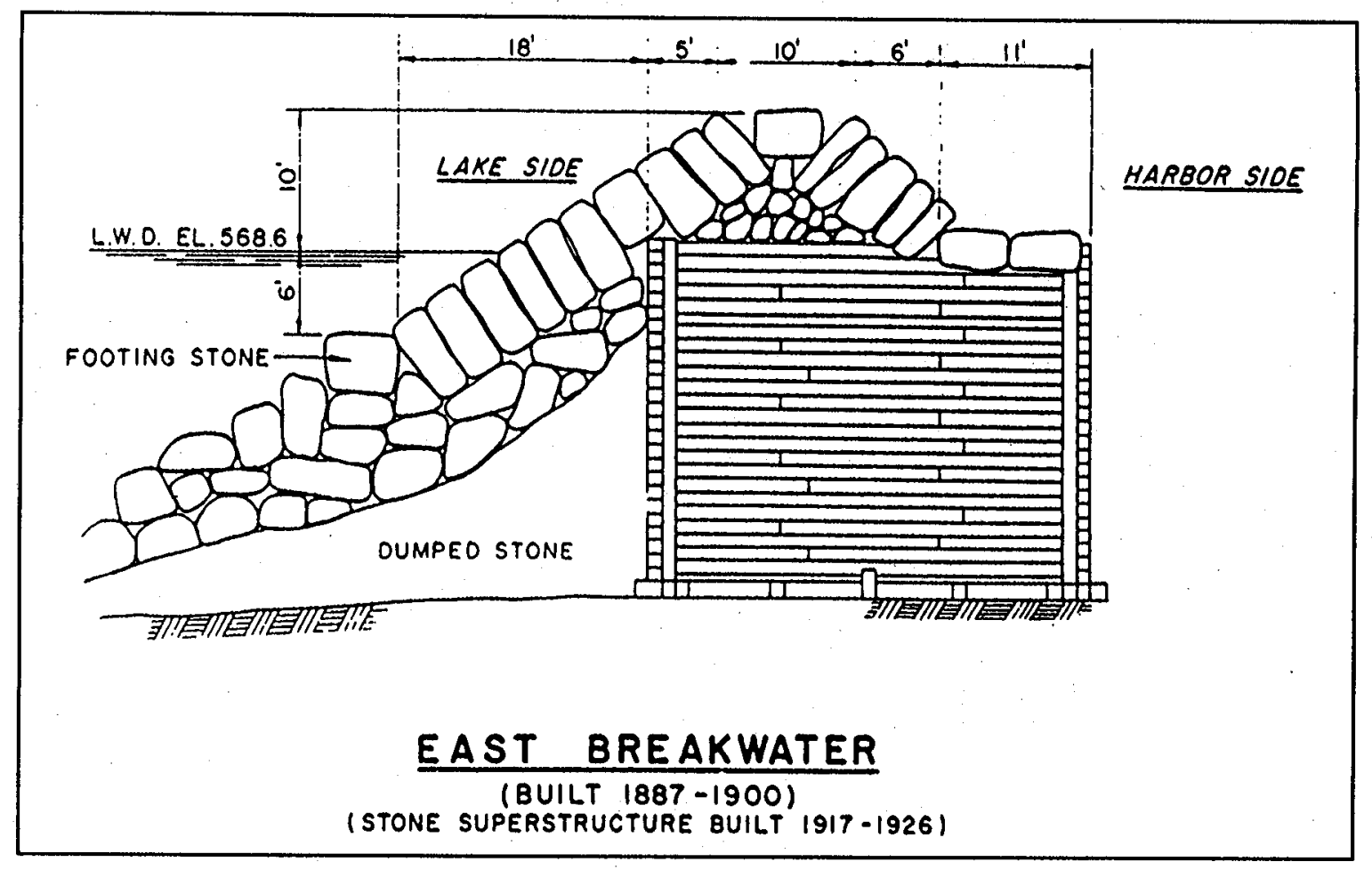

Figure 4. Cross section of western 3,000-ft portion of Cleveland Harbor east breakwater

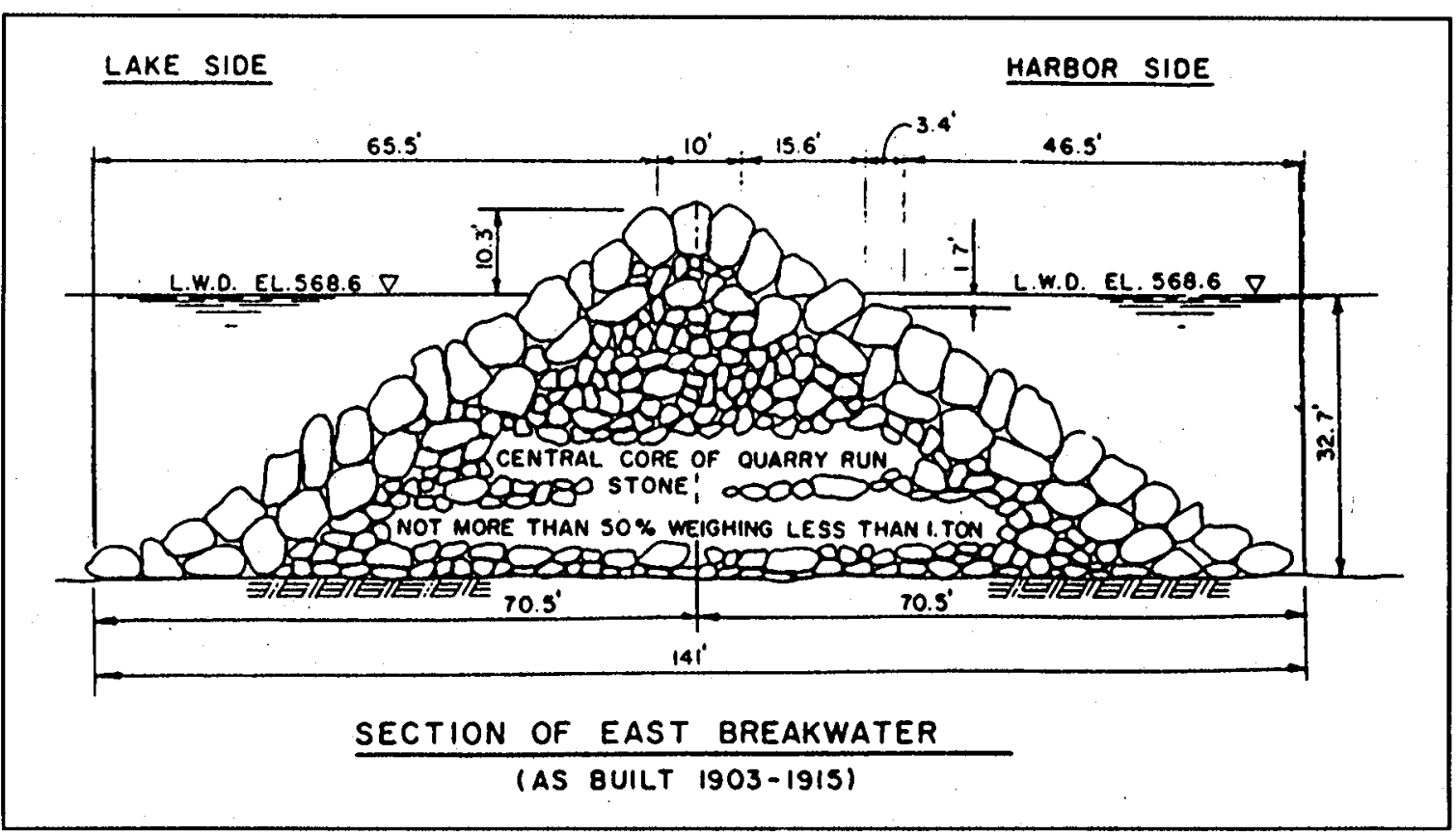

Figure 5. Cross section of eastern 20,970-ft portion of Cleveland Harbor east breakwater as originally constructed 
contracts. During the period 1965-1978, maintenance on the breakwater involved repairs to about 8,000 lin $\mathrm{ft}$ at an expenditure in excess of $\$ 8,000,000$. More information relative to repairs and the history of the Cleveland Harbor breakwaters may be obtained from Bottin (1988b).

The pre-rehabilitated condition of the east breakwater varied between satisfactory and very poor. Portions of the structure were in such critical condition that the breakwater cross section had been breached at several sites and a major rehabilitation project was the only action that could bring the structure back to its design level of protection. Due to the advancing age of the east breakwater, progressive deterioration had reached a point where annual patchwork maintenance was no longer capable of retaining an effective section throughout the length of the structure.

\section{Design of Rehabilitation}

A plan for major rehabilitation at the east end of the east breakwater (USAED, Buffalo 1979) consisted of repairing 4,400 $\mathrm{ft}$ of the structure (Figure 6) with concrete armor units (dolosse). Rehabilitation involved repair of the crest and lakeside of the breakwater trunk between stations $230+00$ and $271+00$ at a slope of $1 \mathrm{~V}: 2 \mathrm{H}$. A slightly flatter slope $(1 \mathrm{~V}: 2.5 \mathrm{H})$ was designed at the breakwater head in order to use the same 2-ton units as cover protection throughout the length of the project and still maintain stability. A 100 -ft-long slope transition zone was established between stations $271+00$ and $272+00$ (between the breakwater trunk and head). The repair of the breakwater head section started at station $272+00$ on the lakeside and continued around to the channel side ending at station $272+00$. The rehabilitation also included rebuilding the breakwater to its authorized project height $(+10.3 \mathrm{ft})$.

A typical section of the rehabilitated breakwater trunk is shown in Figure 7 and a view of the structure is shown in Figure 8. The slope, and in some cases the crest, were rebuilt using 2-ton dolos concrete armor units placed on a $1 \mathrm{~V}: 2 \mathrm{H}$ slope. The layer thickness is equivalent to the average measured thickness of two layers of dolosse randomly placed. Underlying the dolosse, an underlayer stone (Type " $C$," ranging in weight between 600 and 1,300 lb) was placed to provide an even surface with proper gradation on which the dolosse could be placed. The pre-rehab breakwater stone did not infringe in the concrete armor units layer area as the existing structure slope was simply buried.

The cross section of the breakwater head was similar to that of the trunk with the following exceptions. The dolosse slope was constructed $1 \mathrm{~V}: 2.5 \mathrm{H}$ to maintain stability. In addition, the pre-rehabilitated breakwater stone was excavated along the slope to $-22 \mathrm{ft}$ so that the underlayer (Type " $\mathrm{C}$ ") stone could be placed on the slope and crest. The minimum layer thickness of the Type $\mathrm{C}$ stone was $4.25 \mathrm{ft}$ (two layers randomly placed). The existing stone weighing in excess of 0.65 ton and of suitable quality was placed below $-22 \mathrm{ft}$ in conjunction with the Type "B" stone. A view of the dolos-rehabiliated east breakwater head is shown in Figure 9. 


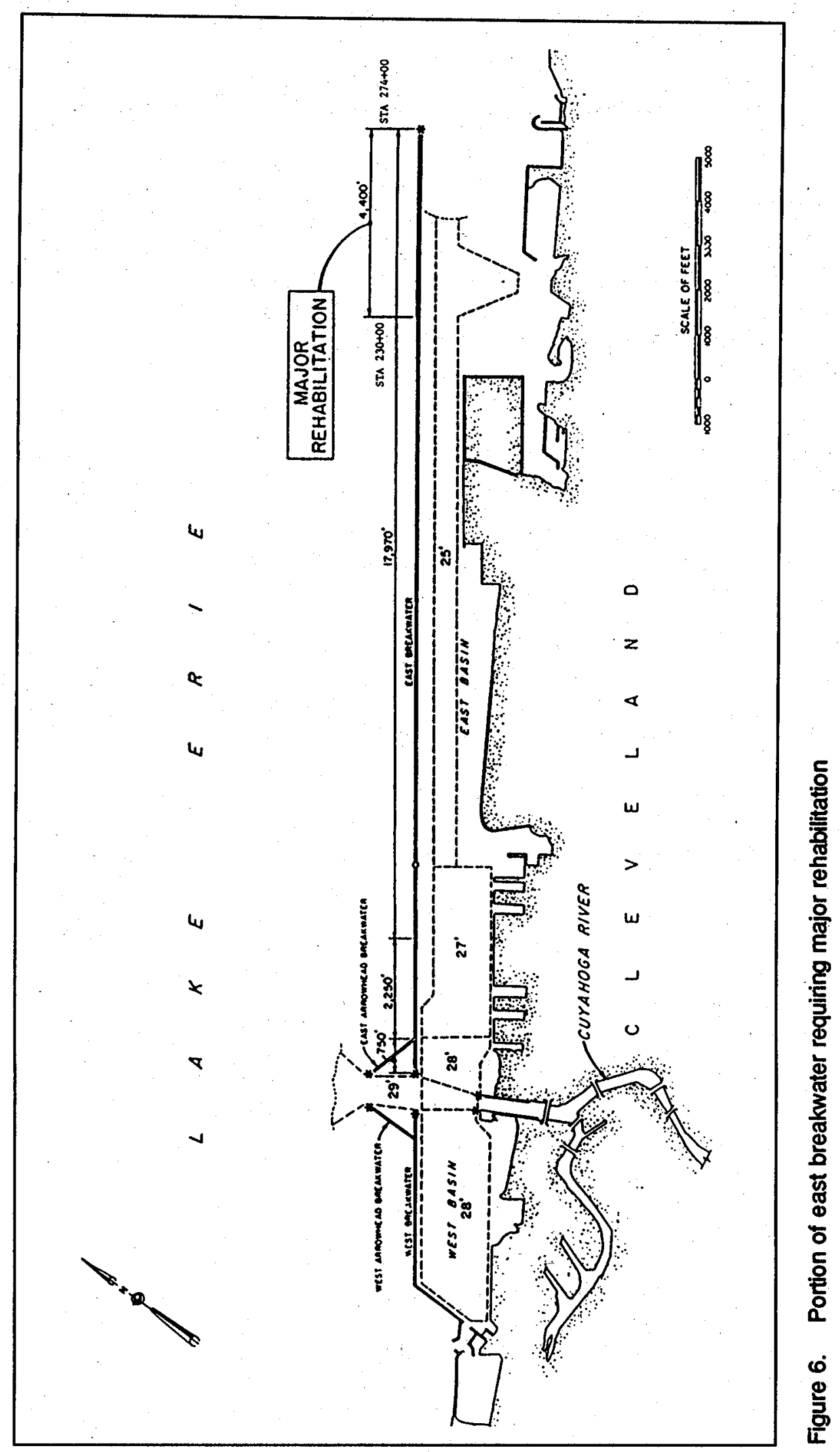




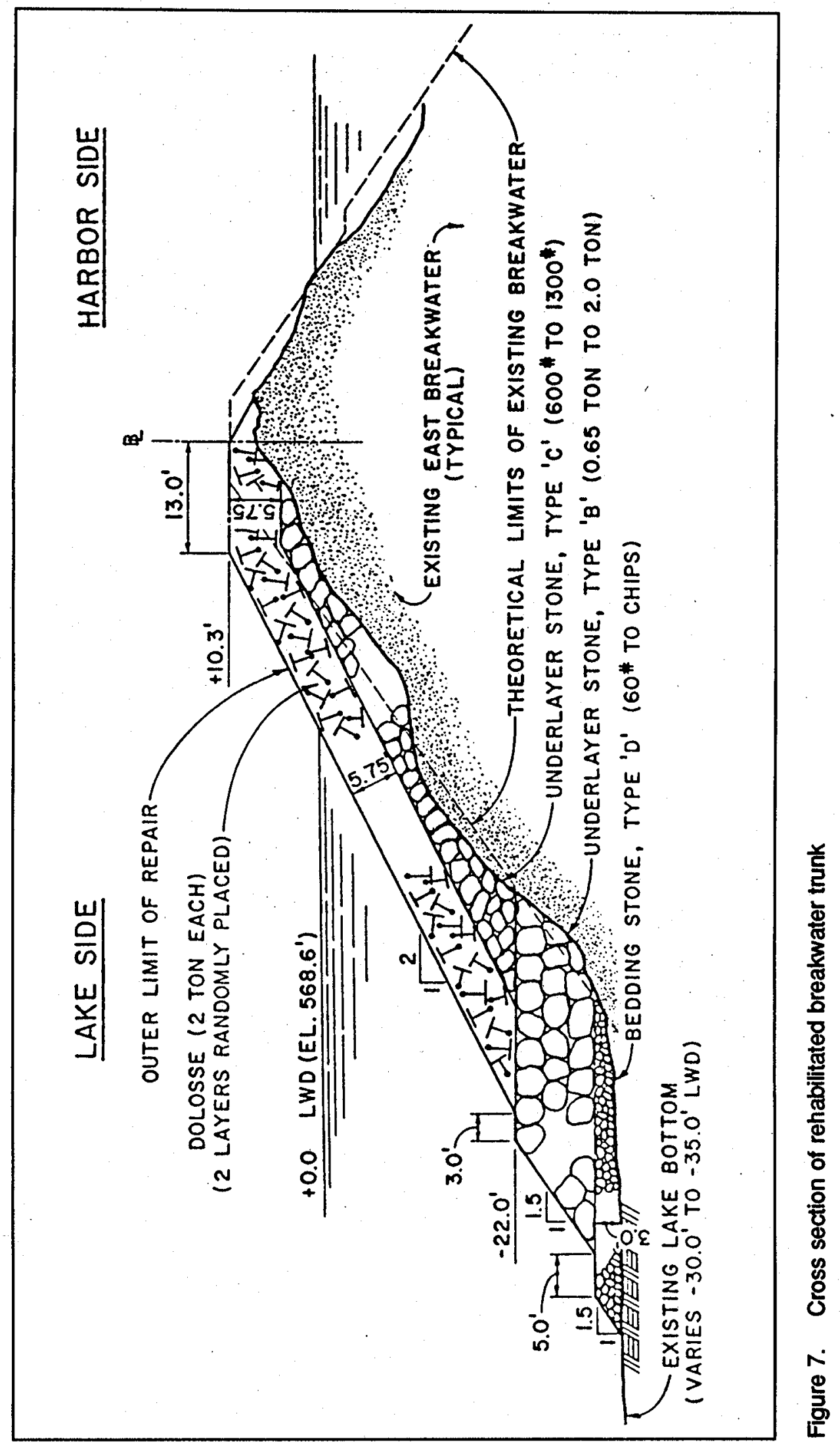




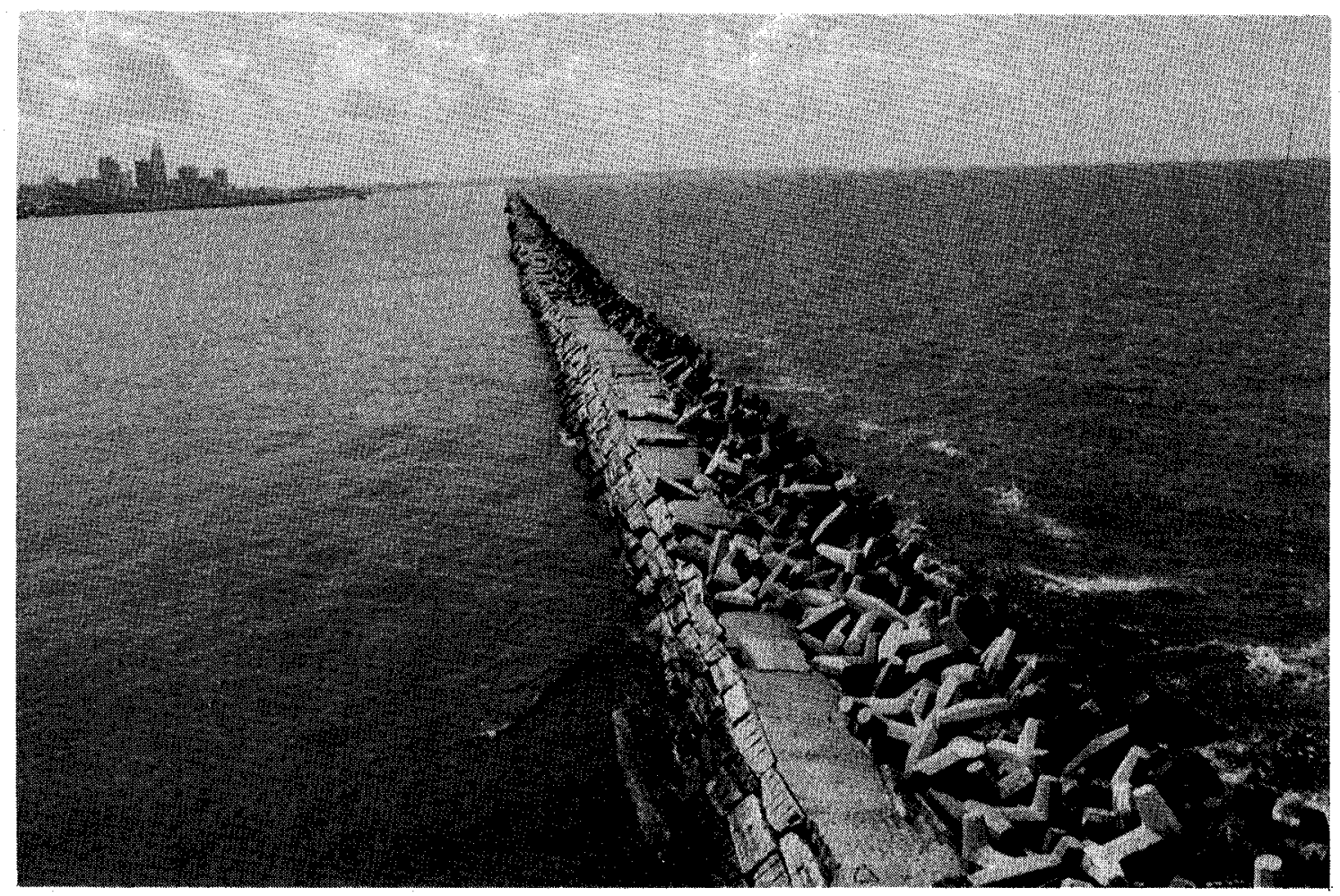

Figure 8. View of dolos-rehabilitated east breakwater trunk (dolosse installed on lakeside of structure)

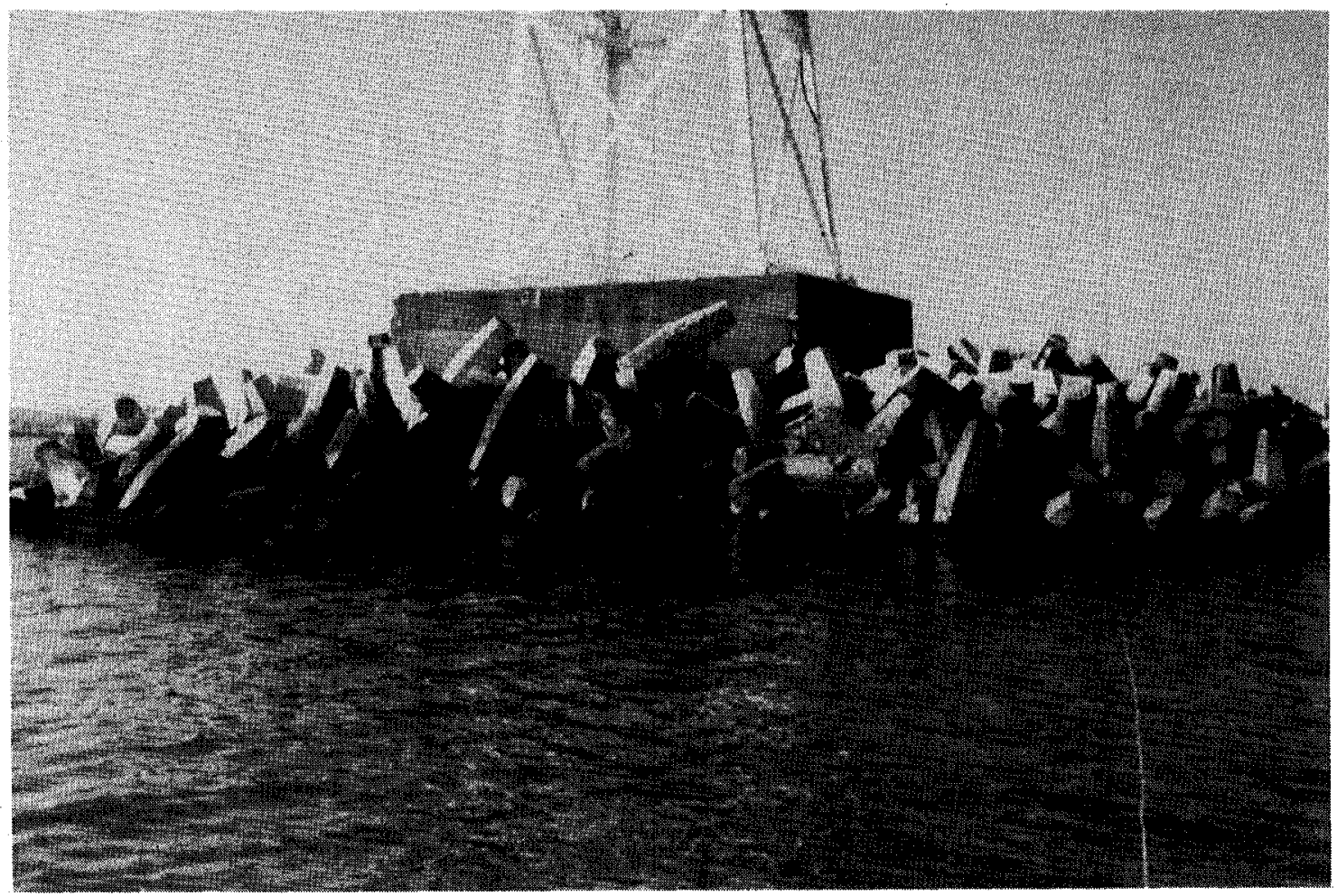

Figure 9. View of dolos-rehabilitated east breakwater head 
Design procedures used to determine the concrete armor size, slope, and layer thickness were obtained from the Shore Protection Manual (SPM 1977) and Hudson (1974). At the time of design, dolosse had the highest stability coefficient and appeared to be the most economical of all concrete armor units being fabricated for breakwater structures. Based on design criteria available, 2-ton dolosse, randomly placed on a $1 \mathrm{~V}: 2 \mathrm{H}$ slope with a two-layer thickness, were adequate to withstand design wave conditions along the breakwater trunk. Flattening the slope to $1 \mathrm{~V}: 2.5 \mathrm{H}$ was necessary at the structure head, however, to achieve stability without increasing the weight of the individual dolos units. The underlayer Type " $\mathrm{C}$ " stone $(600$ to $1,300 \mathrm{lb})$ was placed to provide a leveling layer for the dolosse, and also met the design requirements that the stone weigh between 14 and 26 percent of the weight of the dolosse. The underlayer Type "B" stone placed below $-22 \mathrm{ft}$ and the bedding stone were designed similar to those previously computed for rubble-mound structures.

Design water levels were computed for maximum and minimum conditions. The maximum 10-year occurrence design water level elevation is $+4.9 \mathrm{ft}$. The instantaneous minimum water elevation with a 10-year occurrence interval is $-1.7 \mathrm{ft}$. This value was used to represent the minimum still-water elevation for determining a reference point below which full size armor protection must be placed to resist design wave conditions. As the lake bottom varies between $-30 \mathrm{ft}$ and $-35 \mathrm{ft}$ at the breakwater toe, the maximum design water depth based on the maximum design water level is $39.9 \mathrm{ft}$. The minimum design water depth based on the minimum design water level is $29.7 \mathrm{ft}$. The design wave $\left(\mathrm{H}_{\mathrm{D}}\right)$ is a nonbreaking wave with a height of $13.4 \mathrm{ft}$ and a period of $8.8 \mathrm{sec}$ (Resio and Vincent 1976). This wave was used for determining design size and structural stability for the stone and concrete armor units. Design wave runup computations indicate that there is approximately $15.7 \mathrm{ft}$ of runup for the breakwater as originally constructed, and approximately $12.1 \mathrm{ft}$ of runup for the concrete armor unit design. Thus, runup and wave overtopping with the dolos cover were predicted as being considerably reduced over the prerehab breakwater. However, some wave overtopping of the structure will still occur. Assuming that there is a linear relationship of wave runup to wave transmission, the maximum transmitted wave height should be approximately 80 percent of the maximum transmitted wave for the existing design.

\section{History of Dolos Use}

Dolos armor units (Figure 10) were invented by Mr. Eric M. Merrifield, a South African engineer, in 1963 and first used by him in 1964. Initial model tests of the armor unit were performed by the South African Council for Scientific and Industrial Research in 1965, showing that the dolosse had a stability coefficient significantly higher than any other armor units (Merrifield 1974). Subsequently, other laboratories have tested dolos units and verified that they were more stable than other units. There has been some controversy over the actual magnitude of the stability coefficient since the units were first tested, resulting in different coefficients being published by various researchers. The coefficient has even varied among various editions of the same design manual. 


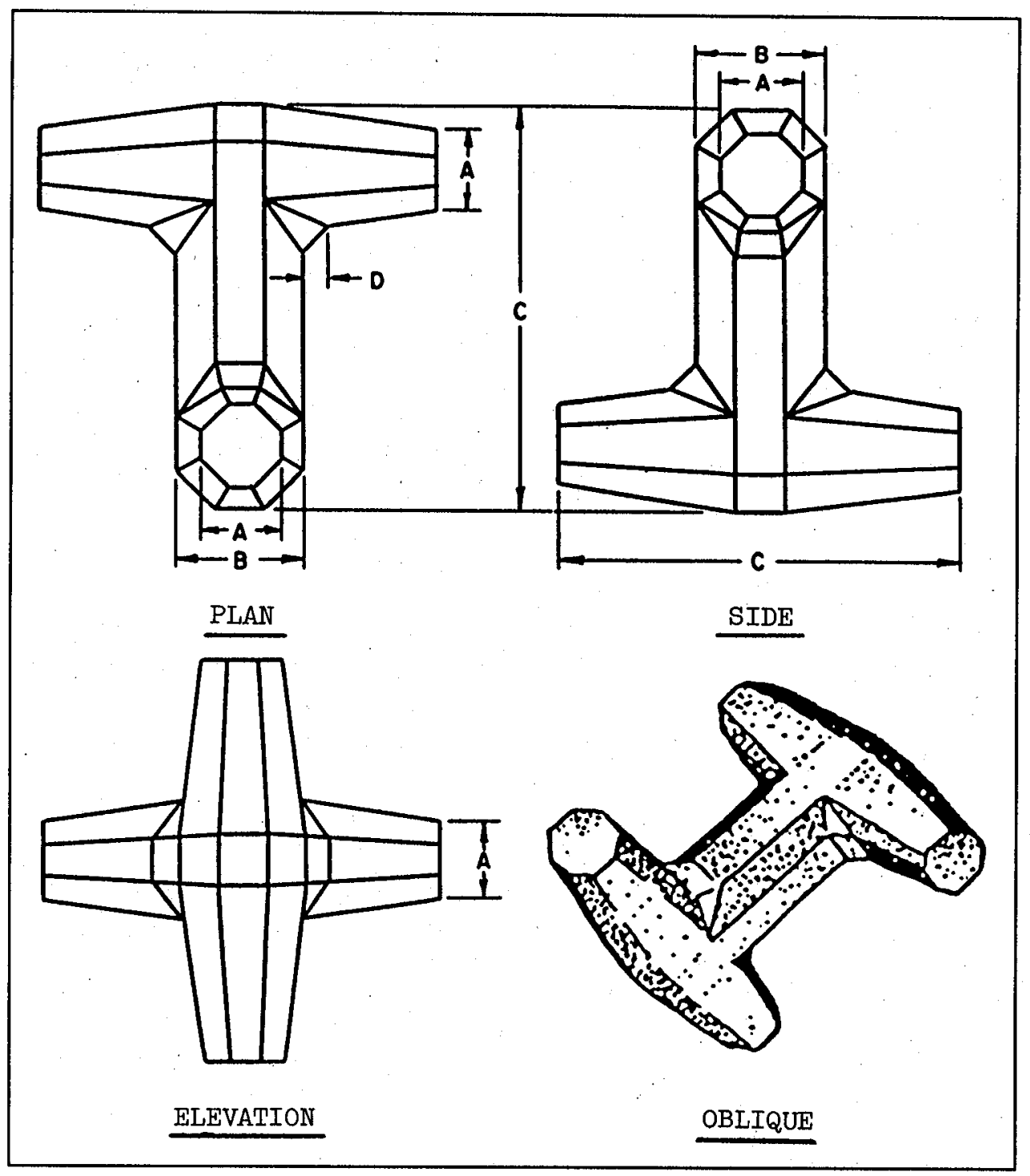

Figure 10. Various views of a dolos armor unit

Because of their exceptional stability, dolosse have been used on a variety of projects throughout the world. In 1981, Zwamborn and Niekerk (1981) reported that 48 projects using dolosse had been built, were being constructed, or were under design throughout the world. Their list did not include the jetties at Manasquan Inlet, New Jersey, or the breakwater rehabilitation at Cleveland, or any other project since 1981 , so the number is greater than 50 .

Between 1963 and the present, many lessons have been learned about dolosse and some engineers have become cautious conceming their use. Spectacular failures, such as one at Sines, Portugal in 1978 (Port Sines Investigating Panel 1982), and the subsequent analysis of the events have revealed shortcomings in the techniques used to test large structures in deep water. The problem is not associated with dolosse alone, but involves the use of any 
armor on deepwater structures where the effect of the larger waves in the spectrum on the survivability of armor units is not well understood.

Reinforcement of dolosse was a rarity at the time of the design of the east breakwater. In South Africa, only some of the dolosse used in Merrifield's original structure were reinforced with only a single piece of scrap rail inserted in the center of the unit. Outside South Africa, reinforcement of dolosse was first tried at Humboldt Bay, California (Bottin 1988a). Subsequently, as reported by Zwamborn, reinforced units were used at Kahului, Hawaii; in Japan; and in Namibia. Unfortunately, little had been reported on the advantages or disadvantages of reinforcing the units, so the decision to reinforce was often left to the judgement of those involved with the structure design.

\section{Monitoring Completed Coastal Projects Program}

The breakwater rehabilitation project at Cleveland Harbor was selected for monitoring under the Monitoring Completed Coastal Projects (MCCP) Program in 1981 as the program's first project during its first year of authorization. The program's goal is the advancement of coastal engineering technology based on project monitoring. It is designed to determine how well projects are accomplishing their intended purposes and are surviving the rigors of the coastal environment. These determinations, combined with concepts and understanding already available, will lead to more credibility in predicting engineering solutions to coastal problems; to strengthening and improving design criteria and methodology; to improving construction practices and cost effectiveness; and to improving operation and maintenance techniques. Additionally, the monitoring program will identify areas where current technology is inadequate or where additional research is required.

To develop the direction for the MCCP Program, the Corps of Engineers established an Ad Hoc Committee of coastal engineers and scientists. The committee formulated the program's objectives, developed its operational philosophy, recommended funding levels, and established criteria and procedures for project selection. A significant result of their efforts was a prioritized listing of problem areas to be addressed, essentially a listing of the program's areas of interest (Table 1). The initial list compiled had only the first 20 items, the final three items were recently added.

Corps Coastal offices are invited to nominate projects for inclusion in the monitoring program when funds are available. Currently, a selection committee, comprised of members of the MCCP Program Field Review Group (representatives of District and Division offices) and civilian members of the Coastal Engineering Research Board, reviews and prioritizes the projects nominated. However, when Cleveland was reviewed, it was prioritized according to how well it met criteria when the MCCP Program was originally formulated. The 


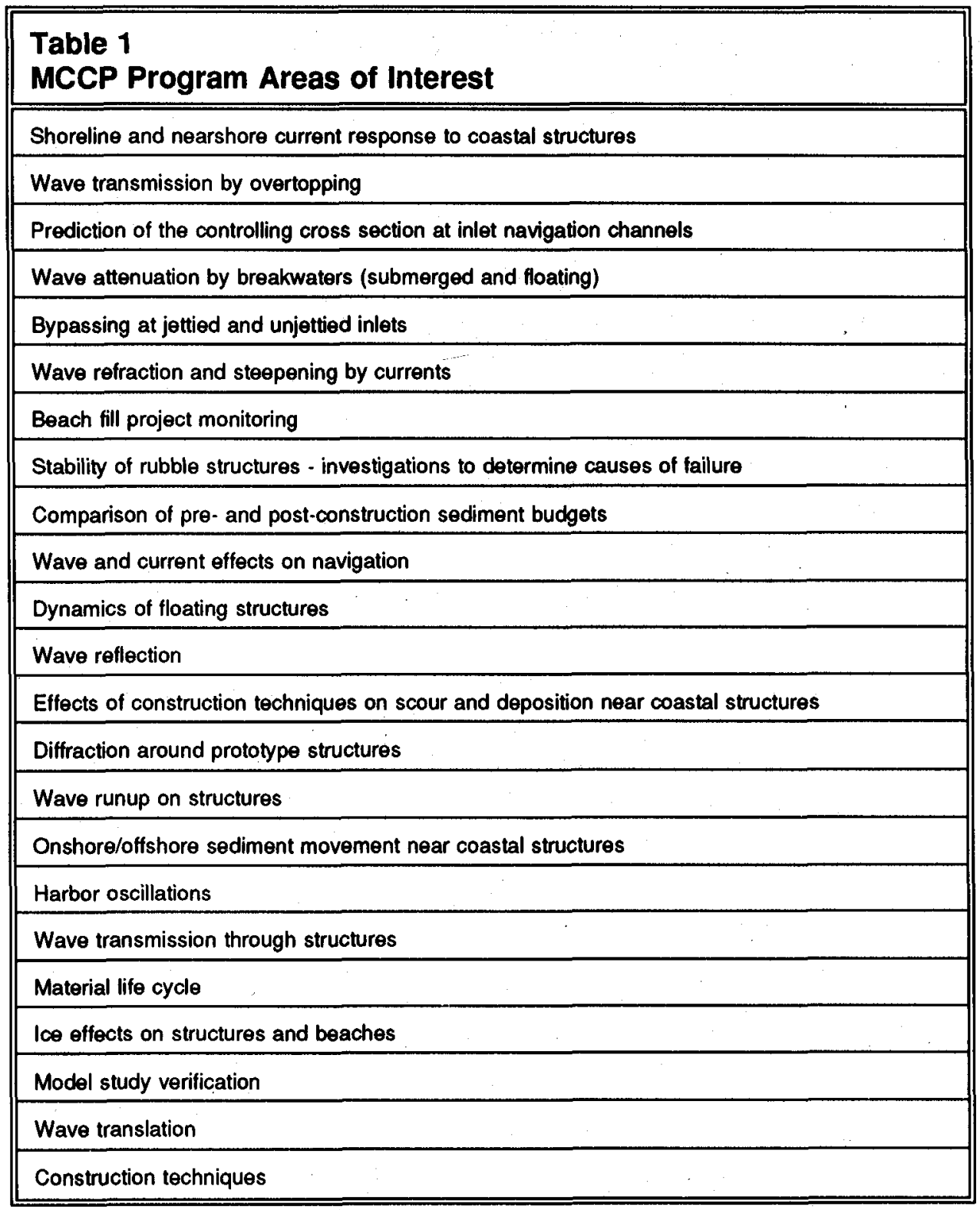

prioritized list is reviewed by the program's Technical Monitors at Headquarters, U.S. Army Corps of Engineers (HQUSACE). Final selection is based on this prioritized list, national priorities, and the availability of funding.

The overall monitoring program is under the management of the U.S. Army Engineer Waterways Experiment Station, Coastal Engineering Research Center (CERC), with guidance from HQUSACE. Operation of the individual monitoring projects is a cooperative effort between the submitting District/Division office and CERC. Development of the monitoring plan and the conduct of data collection and analysis are dependent upon the combined resources of CERC and the Districts/Divisions. 


\section{Monitoring Program}

The primary objective of the Cleveland Harbor east breakwater rehabilitation monitoring plan was to determine the stability of a dolos armor unit cover. This was the first time dolosse were used by the United States in the Great Lakes environment. The monitoring program was also to evaluate the magnitude of armor unit breakage which could compromise the integrity of the structure. Additional objectives were to (a) determine wave transmission by overtopping, (b) qualitatively evaluate runup, and (c) document the effects of ice on the stability of dolos units.

The monitoring program at Cleveland was originally scheduled to cover the period November 1980 - September 1983; however, a severe, near design lake storm was experienced at Cleveland on 6 April 1982. The lake level was driven up to $+6.1 \mathrm{ft}$ above lwd (100-yr frequency) and the hindcast significant wave height was $14.8 \mathrm{ft}$ with a 10-sec period (Driver, Reinhard, and Hubertz 1991 ) in deep water with winds from the northeast. The early spring lake surface also included blocks of winter ice and floating debris which had been washed into the lake during the spring runoff. This ice and debris may have contributed to the impact of the storm on the structure. The storm resulted in observable movement and breakage of dolosse along the breakwater trunk. A zone of many dolosse, above the waterline, was removed from the head on the north side. The damaged head section was repaired in October 1982. As a result of the storm, a reduced monitoring program continued for an additional two years, until September 1985.

\section{Data Collection}

The monitoring program incorporated the use of several observational, direct measure, and remote sensing methodologies. The program included the collection of aerial photography, wave and water level data, survey data to determine armor unit movement above the water line, an inventory of broken dolos units, time lapse photography, and underwater surveys utilizing both side-scan sonar and diver inspections (Pope and Clark 1983). 


\section{Aerial photography}

Controlled aerial photography of the rehabilitated eastern end of the breakwater was obtained periodically over the duration of the monitoring program. Ten reference stations were established between stations $230+00$ and 274+00 at the east entrance light (Figure 11). At each reference station, targets were established, painted, and surveyed along the structure crest for aerial photography control (Figure 12). The aerial missions were flown to produce imagery at a scale of $1 \mathrm{in} .=100 \mathrm{ft}$ with 60 -percent overlap for stereo pair viewing. Black and white film was used since it allowed better resolution for less cost. Mylar enlargements at a scale of $1 \mathrm{in} .=10 \mathrm{ft}$ were developed from the aerials for each flight. Aerial photographs were taken on 30 January 1981, 23 March 1981, 22 May 1981, 31 July 1981, 15 November 1981, 2 April 1982, 4 May 1982, 16 November 1982, 22 April 1983, 27 October 1983, and 31 March 1984.

\section{Wave and water-level data}

Non-directional wave conditions were monitored using two self-contained, pressure-type wave gages (Sea Data Model 635-11) at two locations adjacent to the rehabilitated breakwater. One gage was installed lakeward of the structure, approximately $1,000 \mathrm{ft}$ from station $252+00$ in $38 \mathrm{ft}$ of water, and the other was located $200 \mathrm{ft}$ shoreward of the breakwater inside the harbor, in $27 \mathrm{ft}$ of water. Gage locations are shown in Figure 13. These gages were mounted on bottom-setting, 6-ft-high steel tripods. Data were recorded at $1 \mathrm{~Hz}$ $(1 \mathrm{sec}$ ) for $17 \mathrm{~min}$ every $3 \mathrm{hr}$. Wave records retrieved from the lakeside gage covered the periods 15 July - 1 December 1981 and 26 April - 28 September 1982. Harbor-side wave records covered the periods 15 July - 1 December 1981 and 20 April - 2 July 1982 . The gages were serviced and data tapes replaced every two months during deployment. Winter conditions were not monitored because of the concern that the gages would be lost due to lake ice. Wave data collected were expected to provide an analysis of the wave climate and to measure the magnitude of overtopped waves behind the dolos-protected structure.

Still-water levels on the Great Lakes vary seasonally and annually. Local water levels may also vary instantaneously due to storms or the passage of a front. The lake level is subject to a seasonal rise and fall usually consisting of higher levels in May and June and lower levels in January and February, reflecting regional precipitation and runoff patterns within the Great Lakes Basin. The level of Lake Erie at Cleveland is monitored by the National Ocean Service (NOS) at a location in the Cleveland Lakefront State Park. The lake level data are tabulated and summarized by NOS and made available to other agencies. In addition, lake level information is collected continuously by the Corps of Engineers at the same location and transmitted to the Cleveland Project Office. Therefore, lake level data were continuously available during the entire monitoring period. 


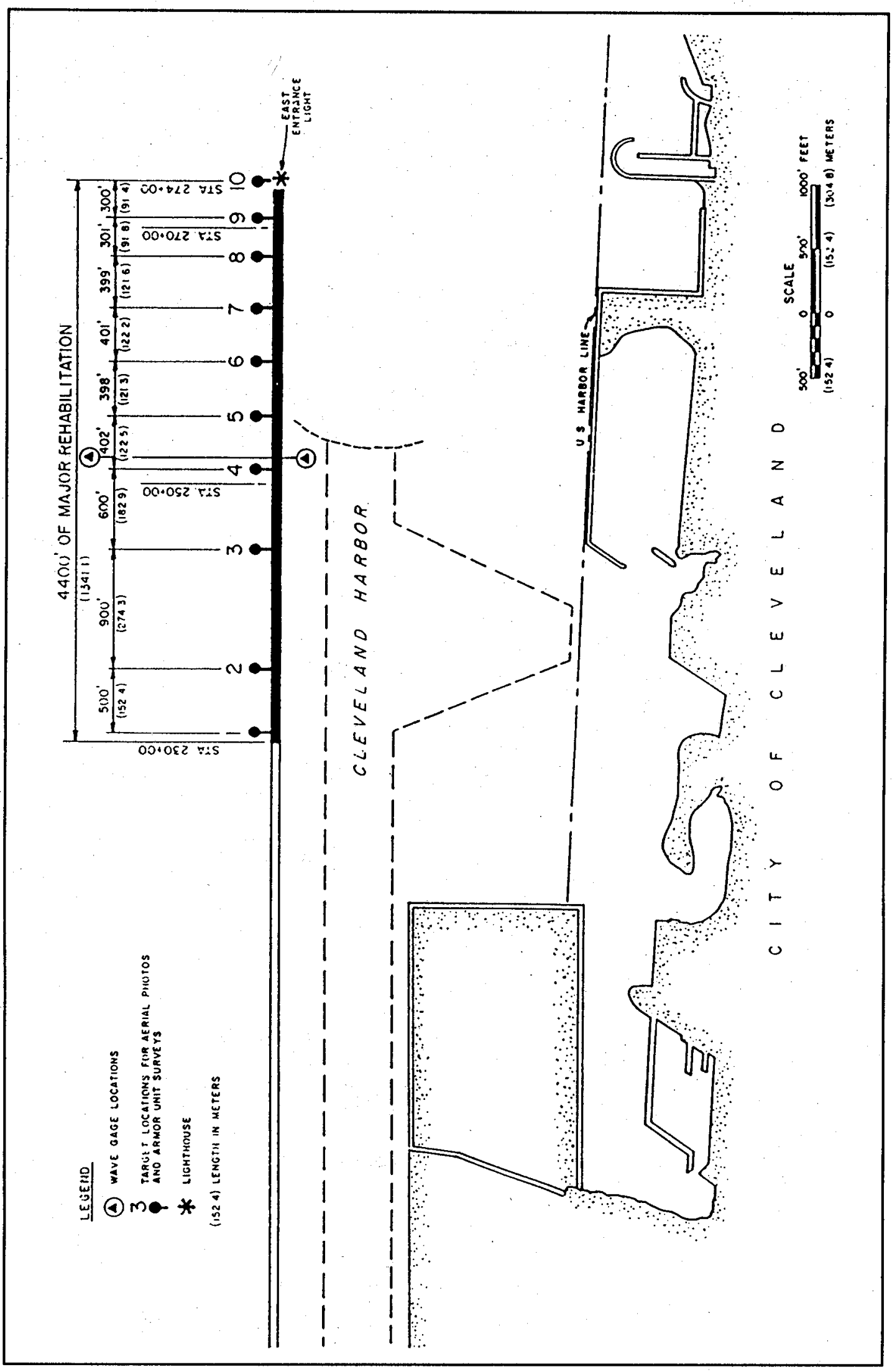

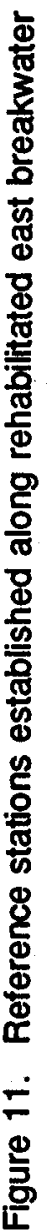



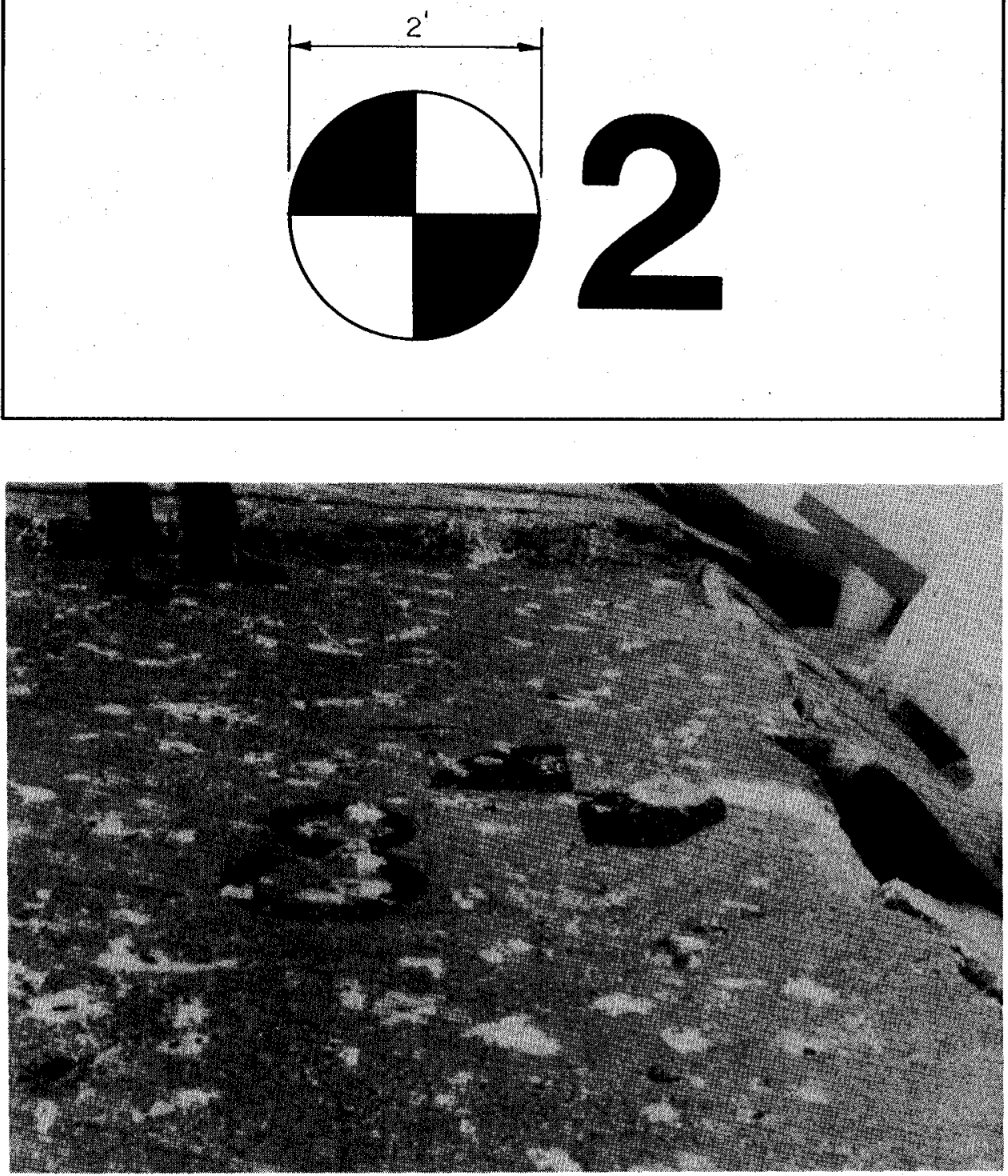

Figure 12. Example of target painted on breakwater crest for aerial photography 


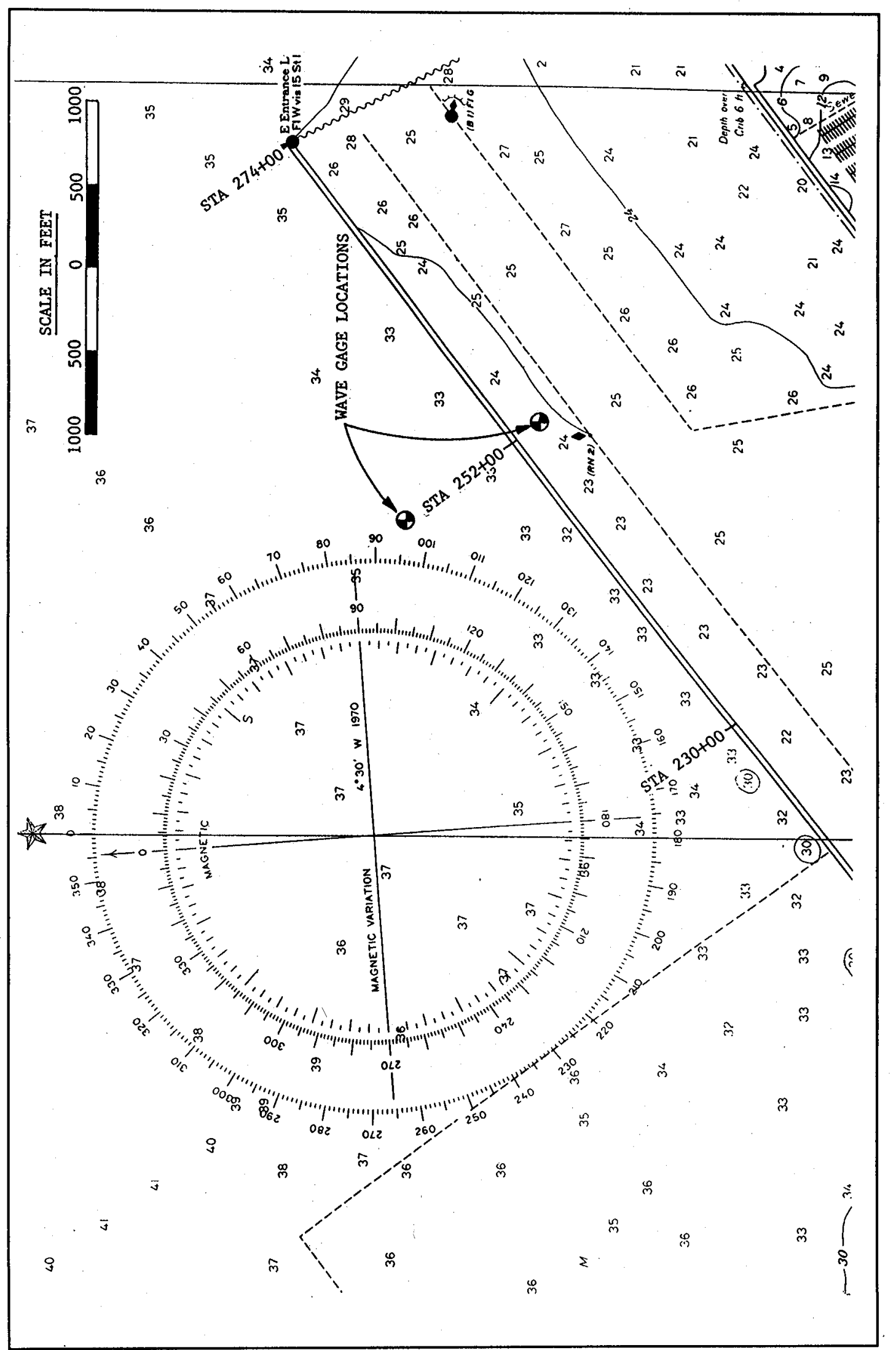

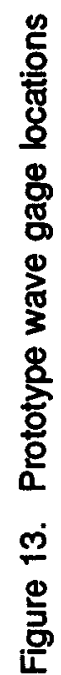




\section{Armor unit movement survey}

Selected dolosse were surveyed in the spring and fall of each year to document individual unit and zone movement during the monitoring period. Survey control points were co-located with the aerial photography targets along the center line of the breakwater crests (Figure 11). At each survey point along the breakwater trunk, two dolosse, one near the waterline and one near the crest, were accurately surveyed at two opposing points on each dolos. At the head of the breakwater, six profile lines were selected at 45-deg angles radiating from a central point on the lighthouse concrete foundation (Figure 14). Two dolosse were selected along each of these lines for monitoring. The 20 dolosse from the trunk and 12 dolosse from the head were painted with a distinctive black pattern (Figure 15) which was obvious and readily identifiable from both the ground and the air and the actual survey point was chiseled into the dolos surface and marked with a yellow circle.

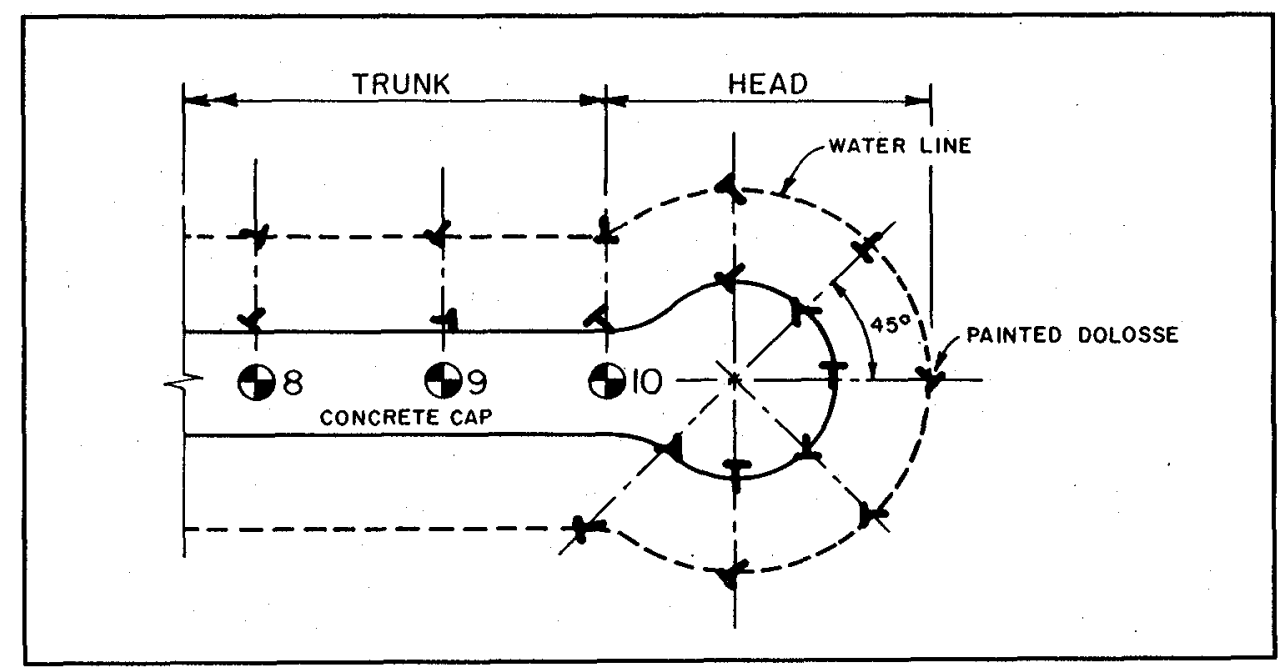

Figure 14. Location of dolosse at the breakwater head identified for armor unit survey

Armor movement was surveyed for each target point to document bearing, north and east coordinates, and elevation. Movement of individual dolosse was analyzed by comparing consecutive surveys, and net changes per zone were evaluated. The surveys were used to measure shifting, sinking, rotation, or loss of individual units at various locations along the structure. Armor unit surveys were completed in December 1980, June 1981, November 1981, May 1982, November 1982, March 1983, November 1983, and June 1984.

\section{Broken armor unlt survey}

Above-the-water inventories of broken dolosse were conducted ten times during the monitoring period. Each dolos is uniquely identified by a casting date and serial number branded into one end of a fluke during original casting. 


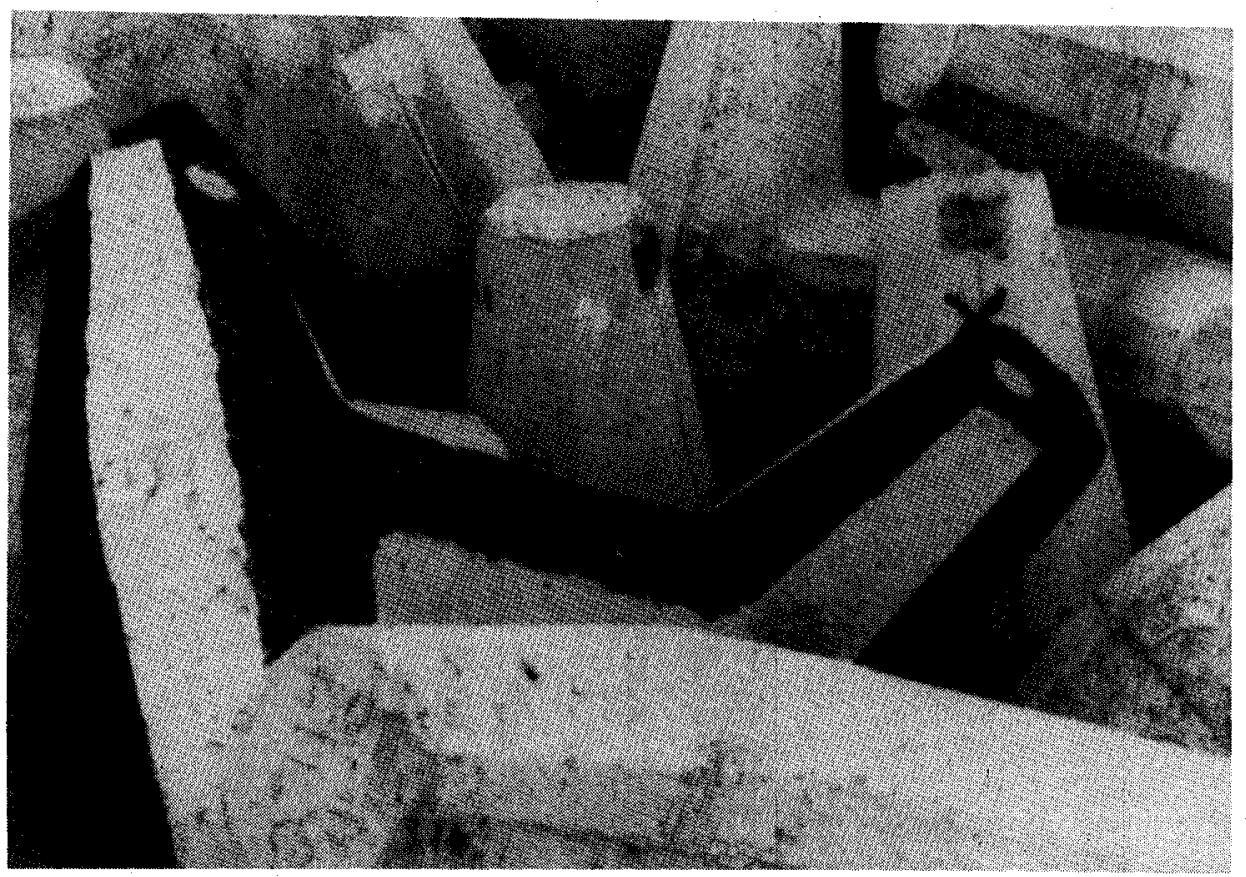

Figure 15. View of a painted dolos used for unit movement survey

During each inspection, the number, date of casting, location relative to the baseline, and type of break were recorded in tabular form for each broken dolosse above the waterline. An example of the form developed for the monitoring effort is presented in Figure 16. A program also was developed to statistically summarize and categorize the dolos breaks. The program sorted breaks from all surveys according to production date, offset from baseline, distribution of breaks along the breakwater, and type of breaks. Breaks were categorized as occurring in the stem or the fluke, and if the break was straight across or at some angle to the dolos limb. Inventories were conducted in June 1980, November 1980, April 1981, November 1981, May 1982, October 1982, May 1983, November 1983, April 1984, and August 1985.

\section{Side-scan sonar survey and diving Inspections}

Side-scan sonar surveys and diving inspections were used to assess the underwater condition of the dolos cover and stability of the toe. A Klein Associates high-resolution, low-range, 500-khz side-scan sonar system was used in April 1981, July 1982, and July 1984, to conduct surveys of the dolosrehabilitated portion of the breakwater. Detailed diving inspections were also conducted at selected areas to assist in interpreting the side-scan sonar record and qualitatively document the extent of underwater dolos breakage. Diving inspections were performed in July 1982, August 1983, and July 1984. 
CLEVELAND HARSOR EAST BREAKWATER REHABIIITATICN

MONITORING PROGRAY

BROKEN DOLOSSE IAVENTORY

DATE: I April'1981

INSPECTUK: J. Matricardi, S. Chong, D. Weidman, J. Bresnahen

\begin{tabular}{|c|c|c|c|c|c|c|c|}
\hline Station & $\begin{array}{c}\text { Offset } \\
\text { from } \\
\text { Baseline } \\
\text { (i) }\end{array}$ & $\begin{array}{l}\text { Dolosse } \\
\text { Number }\end{array}$ & $\begin{array}{c}\text { Production } \\
\text { Date }\end{array}$ & $\begin{array}{l}\text { Type } \\
\text { of } \\
\text { Break } \\
(2)\end{array}$ & $\begin{array}{l}\text { Break } \\
\text { Separation } \\
\text { Distance } \\
(3)\end{array}$ & $\begin{array}{l}\text { Photo } \\
\text { Number }\end{array}$ & $\begin{array}{c}\text { Coniments } \\
(4)\end{array}$ \\
\hline $230+20$ & $13 !$ & visible & - & SI & $2^{\prime}$ & $14-14$ & \\
\hline $230+27$ & $10^{\prime}$ & 15800 & $5-31-80$ & F2 & $0^{\prime \prime}$ & $24-15$ & \\
\hline $230+30$ & $29 !$ & visible & - & S1, s1 & $3^{\prime}$ & $14-16$ & 2 Breaks \\
\hline $230+35$ & $5^{\circ}$ & 2481 & $12-6-79$ & $F / 2$ & $15^{\prime \prime}$ & $1-1$ & \\
\hline $230+40$ & $29^{\prime}$ & 13260 & $4-24-80$ & si & $2^{\prime}$ & $14-17$ & \\
\hline $230+45$ & $18^{\prime}$ & 902 & $11-5-79$ & S1 & $0^{\prime \prime}$ & $14-18$ & \\
\hline $230+50$ & $25^{\circ}$ & vigible & $=$ & $F / 2$ & $2^{\prime \prime} /$ missing & No Photo & misingeg $4916 / 81$ \\
\hline $230+70$ & $17^{\prime}$ & visible & - & s1 & $6^{\prime}$ & $24-19$ & \\
\hline $230+70$ & $10^{\prime}$ & 11006 & $3-31-80$ & $\sqrt{2}$ & $7^{\prime \prime}$ & $14-20$ & \\
\hline $230+73$ & $20^{\prime}$ & 11013 & $3-31-80$ & F2 & 1 & $14-21$ & \\
\hline $230+75 \cdots$ & $26^{\prime}$ & $\begin{array}{l}\text { not } \\
\text { visible }\end{array}$ & - & $\mathrm{s} 2$ & $3^{\prime}$ & $14-26$ & \\
\hline $230+83$ & 8. & 10922 & $3-29-80$ & $F 2, F 2$ & Both 6' & $6-20$ & 2 Breaks \\
\hline $231+05$ & $20^{\prime}$ & 1362 & $11-14-79$ & $\mathrm{s2}$ & mpssfys & $14-22$ & \\
\hline $231+07$ & $15^{\prime}$ & 1505 & $11-19-79$ & $F 2$ & $\begin{array}{l}\text { piece } \\
\text { misinn }\end{array}$ & $6-22$ & \\
\hline $231+10$ & $9^{\prime}$ & 1521 & $11-19-79$ & $\mathrm{~s} 2$ & $5^{\prime \prime}$ & $i-4$ & \\
\hline $231+15$ & $10^{\prime}$ & 1859 & $11-28-79$ & S1 & 6" & $6-23$ & \\
\hline $231+18$ & $19^{\circ}$ & 1320 & $1.1-14-79$ & si & $2^{\prime}$ & $6-24$ & \\
\hline $231+35$ & 81 & 1956 & $11-29-79$ & $\mathrm{~s} 2$ & $7^{\prime \prime}$ & $2-5$ & \\
\hline $231+40$ & $23^{\prime}$ & 2424 & $12-10-79$ & BI & है! & $6-25$ & 2 Breaks \\
\hline $231+90$ & $17^{\prime}$ & 2087 & $11-30-79$ & 51 & $2^{\prime}$ & $7-1$ & \\
\hline $231+92$ & $20^{\circ}$ & 2235 & $12-4-79$ & si & 21 & $7-2$ & \\
\hline $231+94$ & $22^{\prime}$ & viśliste & - & s1 & $3^{\circ}$ & $14-23$ & \\
\hline
\end{tabular}

1. Ajproximate Distance off of $Q$

n. Broken. From 6/18/80. Survey

2. Use following code:

F - Fiuke break

$S$ - Sten break

* Use if numbered fluke

BDP Broken During Placement

** Rroken From 11/17/80 Survey

1 - Straight break

2 - Angle brak

3. Approximate Distance Separating Dolo Parts

4. Corments should include if broker, down piacement, target dolo, red, black or yollow.

Figure 16. Example of form developed for monitoring broken armor units

\section{TIme-lapse photography}

Time-lapse photography was included in the original monitoring plan. This activity was intended to obtain a limited period of time interval imagery of the dolos-covered breakwater during daylight hours while the wave gages were in 
place. The photography would document behavior of the armor layer during storms (particularly movement or rocking of individual units as well as runup and overtopping relative to a specific wave climate). However, during design of an automatic electronic triggering mechanism which would obtain movie footage only during periods of daylight with the correct wind direction and strength, this phase of the monitoring program was found to be very costly. Therefore, time-lapse photography was dropped from the monitoring program due to the expense.

\section{Monitoring Results}

\section{Armor unit movement}

The April 1982 storm resulted in movement and breakage of some dolosse along the breakwater trunk and removal of nearly all the dolosse above lwd over a 20 -ft-wide section at the breakwater head. Observations and scrape marks along the concrete cap of the trunk also indicate that some units slid; flipped, or were thrown to the harbor side of the structure during the storm. About 65 dolosse were "popped" away from the impermeable, vertical-faced lighthouse concrete block base and strewn downslope as broken fragments. As a result of the storm, 200 additional dolosse were placed on the head section in October 1982 to repair the damage zone and widen the head section crest (from a two-dolos width to a three-dolos width). New target dolosse were identified and monitored. Target dolos density and the number of inspections for the head section were increased. Twenty-one new dolosse were designated for survey following the April 1982 storm. During the October repair, displaced dolosse along the trunk section also were repositioned and additional units were placed as necessary.

Of the 20 target dolosse established initially along the breakwater trunk, data were collected for 12 units over the entire monitoring program. The other eight dolosse were either lost, broken, or inaccessible. Three of these missing armor units were replaced by new target dolosse between the November 1982 and March 1983 surveys. The dolosse at the crest of the breakwater proved to be considerably more stable than those at the waterline. Of the ten target dolosse at the waterline, four were missing, two were broken, and one was inaccessible at the end of the monitoring period. The remaining three settled into the structure. One of the crest dolos was lost, and the others settled into the structure.

On the head section of the breakwater, only four of the twelve target dolosse have remained intact throughout the monitoring period. Many of the head section dolosse were either lost or inaccessible after the April 1982 storm and subsequent repair. As with the trunk section, the head section dolosse near the waterline moved more than those at the crest. The waterline target dolosse in the head section area, which is exposed to direct wave action, moved considerably. Even the dolosse on the sheltered harbor side of the head moved. Four of the six original waterline target dolosse were missing, 
whereas only one of the six crest dolosse was lost. Of the six target dolosse originally placed at the crest, one was lost and one inaccessible.

In the fall of 1982, 19 new additional target dolosse were established on the head section of the breakwater. These units were surveyed in March 1983 and June 1984. The movement of the majority of these dolosse was characterized by settlement or rotation into the structure. Settlement is when a dolos loses elevation uniformly and rotation involves one end of the dolos rising while the other end loses elevation. Two of the new units were missing during the second survey. The dolosse on the shore side of the head section moved less than those on the lakeside.

The magnitude of average targeted dolos motion between surveys for the trunk and head sections is shown in Table 2. These values were derived by averaging the absolute horizontal and vertical motion vectors for each dolos point between surveys. Lost dolosse were ignored. The actual significance of each value is obscure and is only used to illustrate general stability of the dolos cover through time. Evaluation of the movement data reveals that movement continued for those dolosse which remained intact throughout the monitoring period. Some dolosse were stable for a while, then began moving again. Therefore, the majority of the armor units continued to settle, and the dolos cover did not stabilize during the monitoring time frame. During the period all surveyed dolosse lost elevation. In summary, the dolos cover was dynamic throughout the monitoring period and maximum cover stabilization was never realized.

\section{Table 2}

Average of Motion Vectors, $\mathrm{ft}$

\begin{tabular}{||l|l|l|l|l|l|l||}
\hline \hline Section & $\begin{array}{l}\text { Dec 80- } \\
\text { Jun 81 }\end{array}$ & $\begin{array}{l}\text { Jun 81- } \\
\text { Nov 81 }\end{array}$ & $\begin{array}{l}\text { Nov 81- } \\
\text { May 82 }\end{array}$ & $\begin{array}{l}\text { May 82- } \\
\text { Nov 82 }\end{array}$ & $\begin{array}{l}\text { Nov 82- } \\
\text { Mar 83 }\end{array}$ & $\begin{array}{l}\text { Mar 83- } \\
\text { Jun 84 }\end{array}$ \\
\hline \hline Trunk Section & 0.7 & 0.2 & 0.8 & 0.2 & 0.2 & 0.6 \\
\hline Head Section & 1.2 & 0.5 & N/A & N/A & 0.1 & 0.2 \\
\hline
\end{tabular}

A graphic representation of targeted dolos movement over time was also developed in the monitoring program. Figures 17 and 18 present the net movement of surveyed dolosse along the breakwater trunk and head sections, respectively, for various time intervals.

\section{Broken armor units}

Evaluation of the broken dolos survey results from April 1980 to September 1985 indicates a total of 692 broken units above the waterline. The number of newly inventoried broken dolosse per individual survey is shown in Figure 19. The rate of new breakage appears to have decreased with time as shown by the cumulative number of broken units during the monitoring period (Figure 20). 


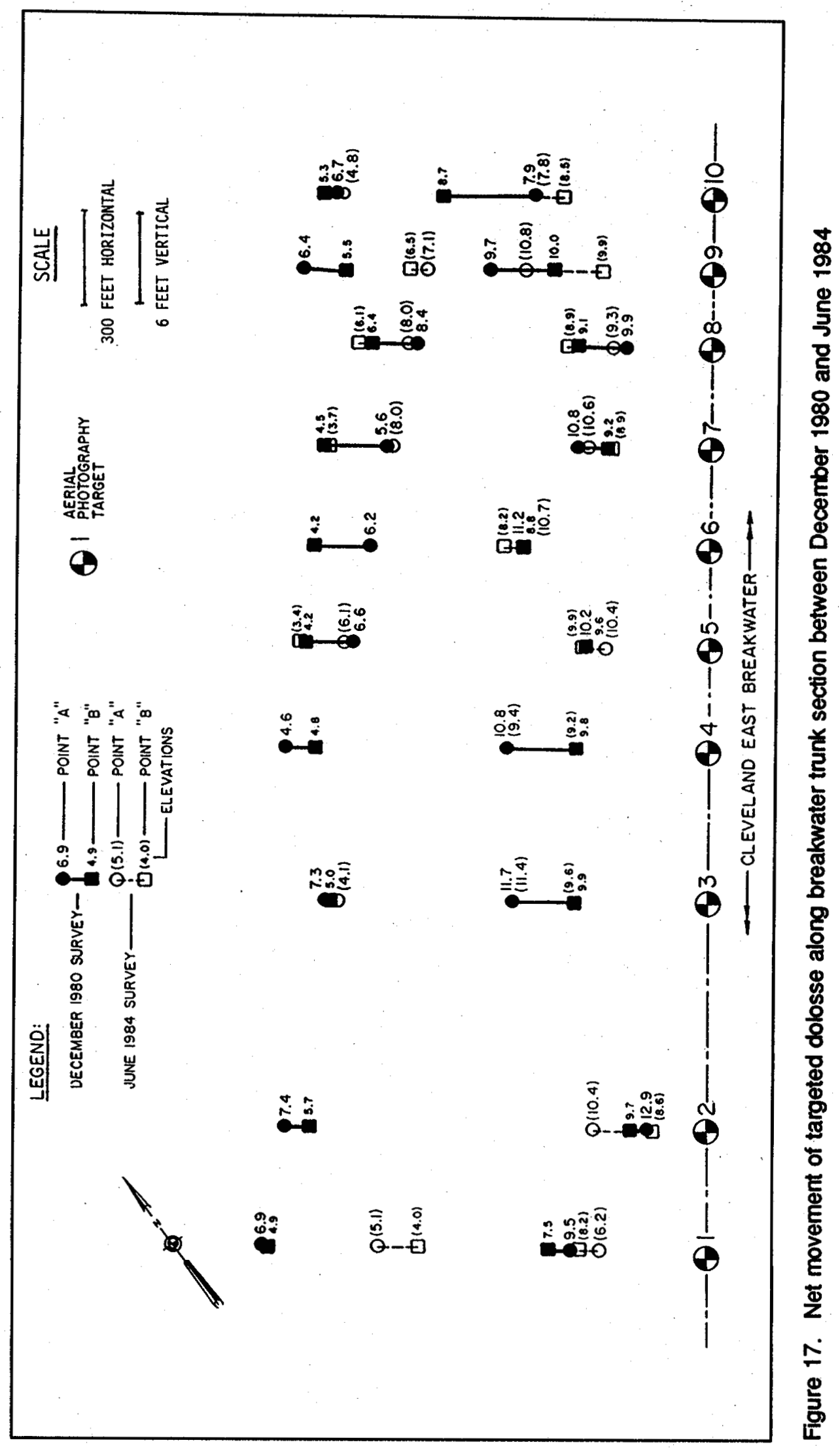




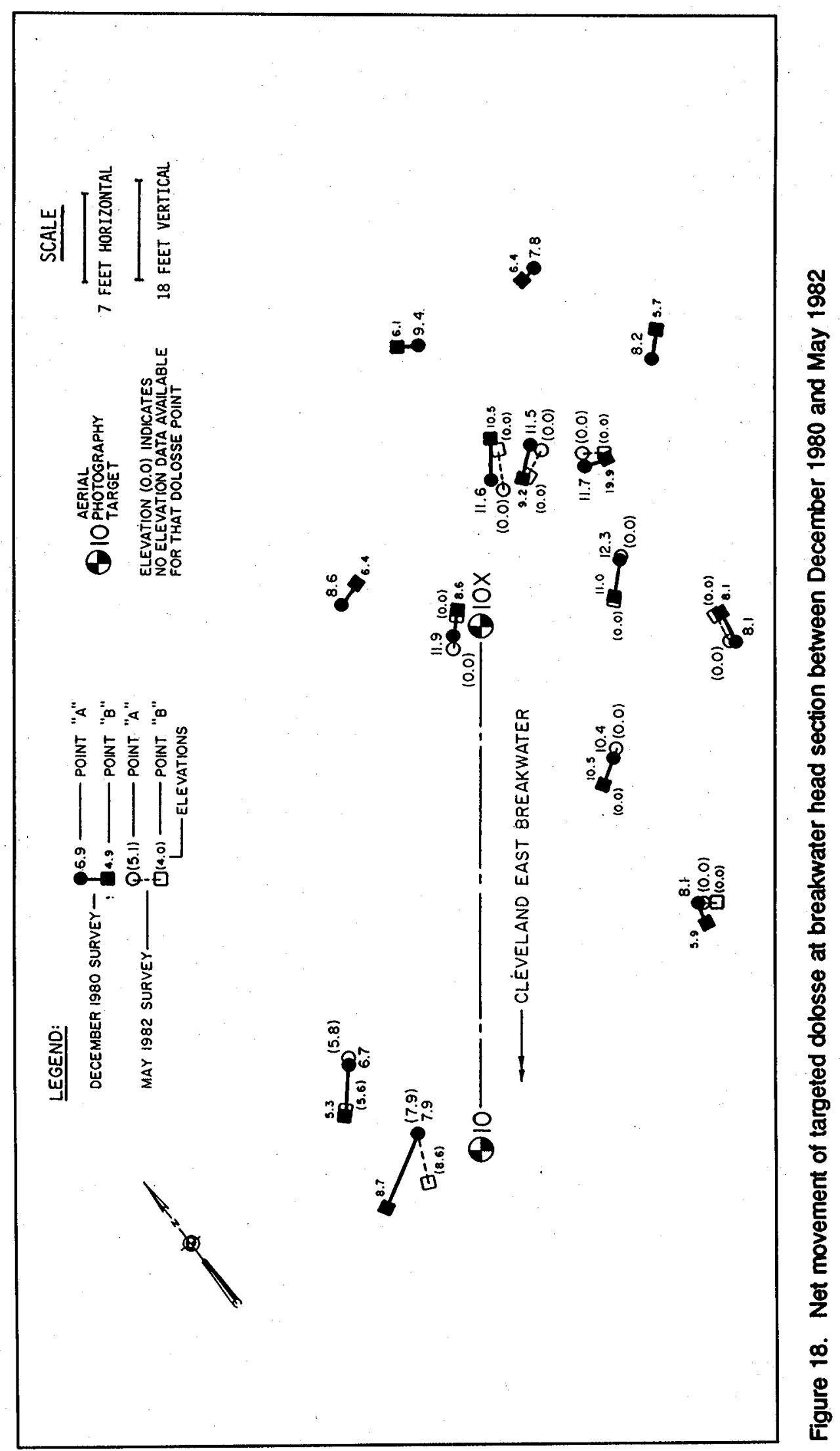




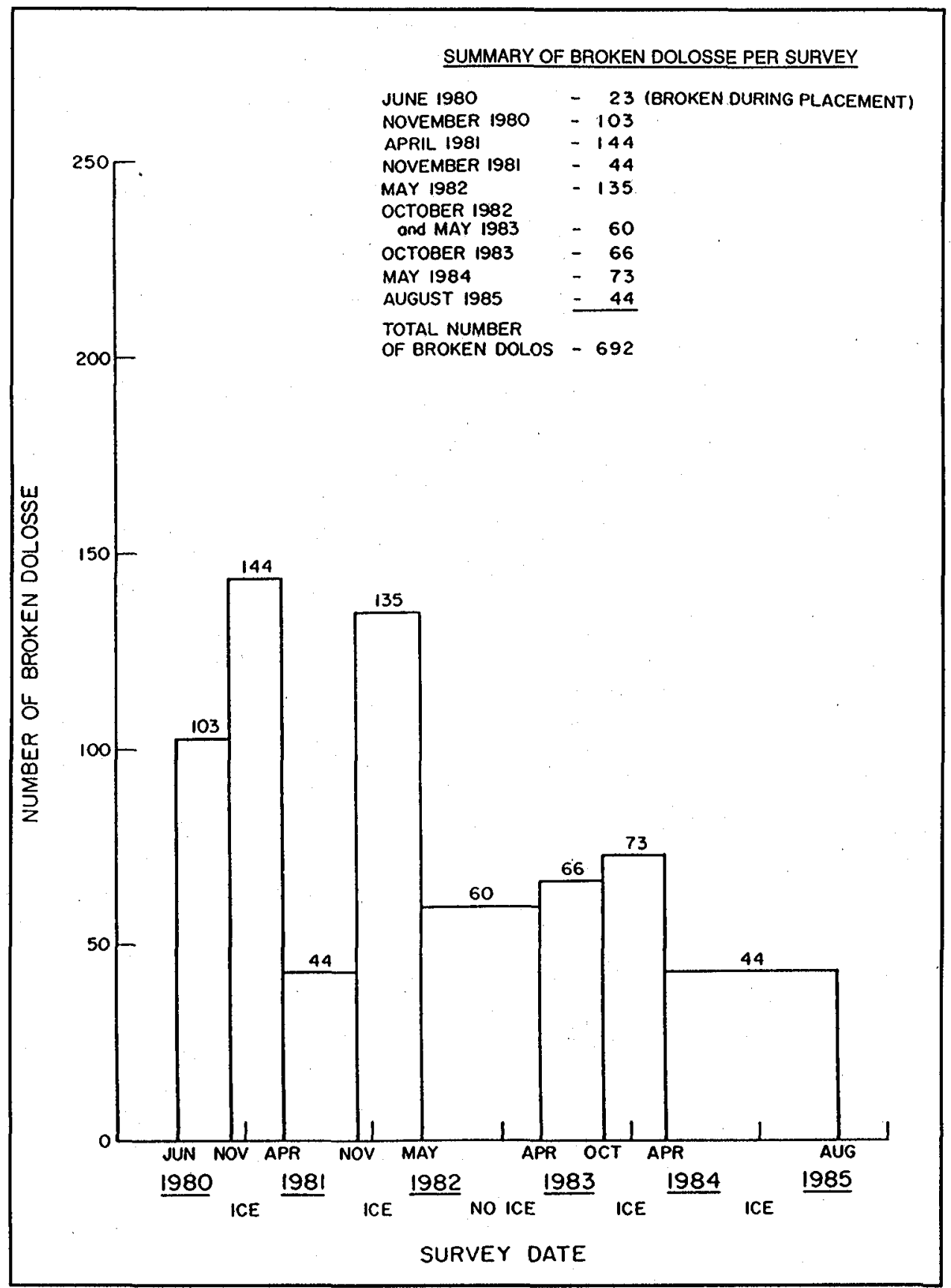

Figure 19. Number of broken dolosse identified in individual surveys

Approximately 30 percent of the dolosse were placed above the average annual mean lake level during construction. Therefore, about 8,972 dolosse of the total 29,741 were placed above the waterline within the primary wave impact zone. With 692 units broken, this yields approximately an 8-percent breakage rate over the monitoring period ignoring below-water breakage.

During the years when semiannual surveys were conducted, there was a distinct difference between the number of units broken in the summer and 


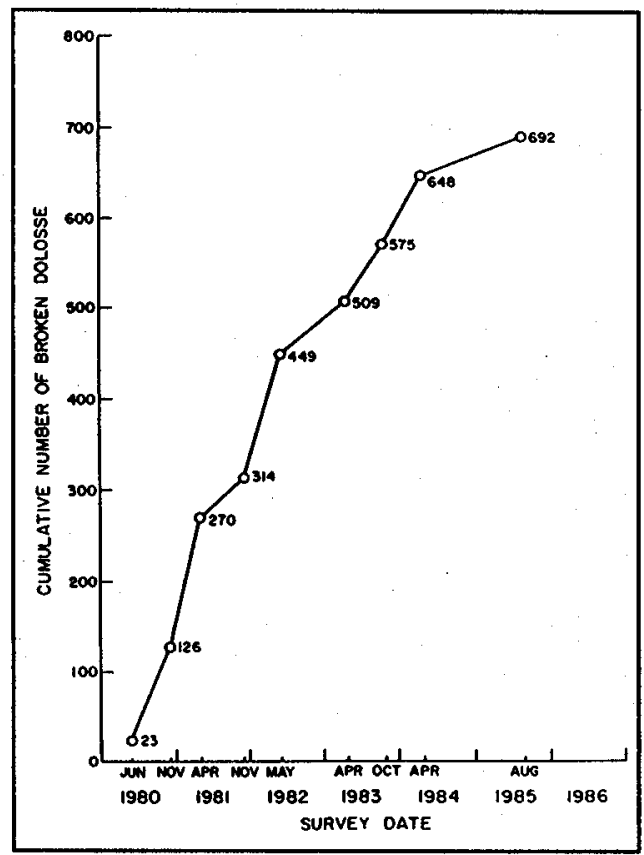

Figure 20. Cumulative number of broken dolosse during the monitoring period winter months. Breakage was considerably greater from November to April than from the period April to November. A combination of increased storm activity and the effect of ice on the structure during the winter months probably contributed to the greater breakage rate.

Information on the type of break also was obtained. Figures 21 and 22 depict representative angled and straight fluke and stem breaks in various dolosse. The majority were fluke breaks, and the number of angled breaks exceeded the number of straight breaks. The majority of fluke breaks were angled, whereas the stem breaks exhibited no dominance of either angled or straight breaks.

Comparison of breakage to production data showed that no production group had an unusual amount of breakage. The average breakage per month of production was about 2 percent. Evaluation of the data with regard to offset from the baseline along the crest indicates that the majority of breakage occurred between 15 and $25 \mathrm{ft}$ lakeward of the baseline, which is near the waterline.

In general, the rate of breakage fluctuated over the monitoring period, though new breaks appeared to be decreasing during the last survey. Over one third of the breakage occurred during the first year. Almost 60 percent of the breakage occurred between June 1980 and April 1981 and November 1981 and May 1982, which covers the first year following construction and the period surrounding the April 1982 storm. Although not conclusive, it appears that breakage may increase during winters when ice coverage forms. Changes in the breakage rate can be accounted for partially by settling of the dolos cover. Also, differences in the water level will change the number of units visible during a survey, thereby influencing the broken dolos count during periods of high or low water. Reasons for dolos breakage may include (a) stress patterns within the original cast dolosse, (b) handling and placement, (c) settling of the structure, stressing units within the breakwater, (d) wave-induced displacement, (e) wave-induced rocking and fatigue failure, (f) ice pressure and movement, and (g) impact from debris and dolos fragments. 


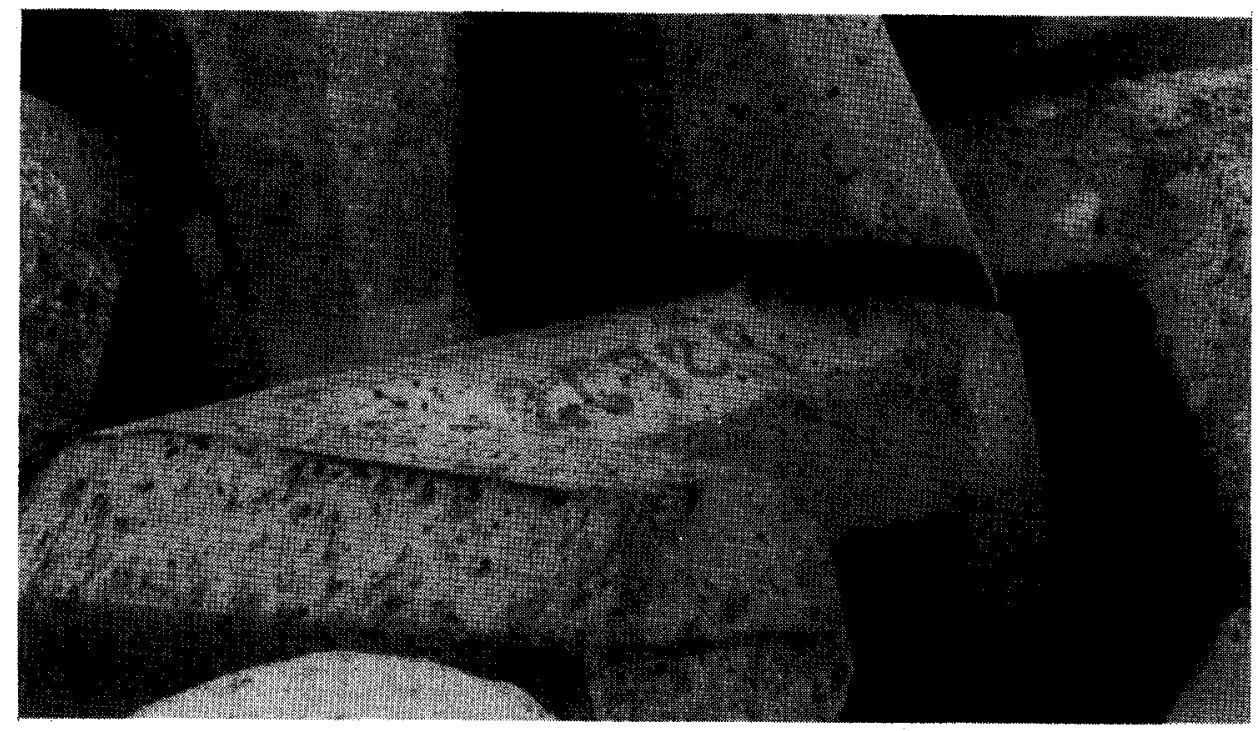

a. Angled fluke break

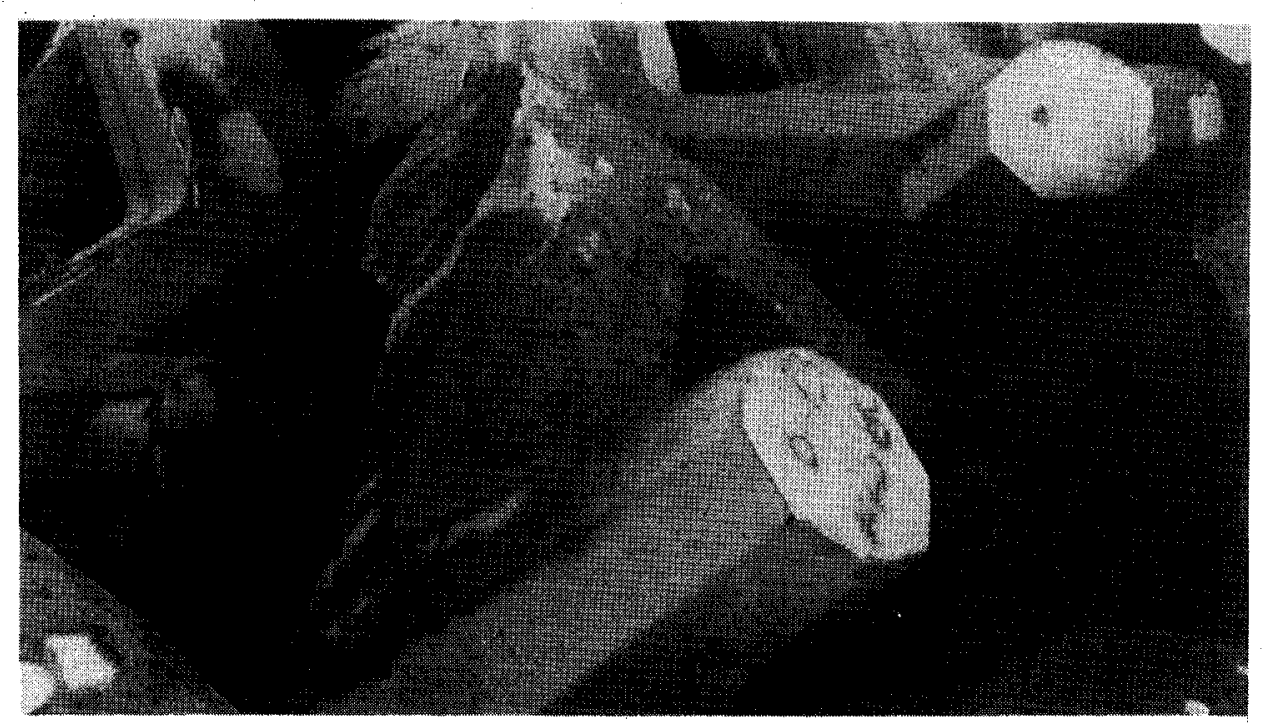

b. Straight fluke break

Figure 21. Dolosse with straight and angled fluke breaks 


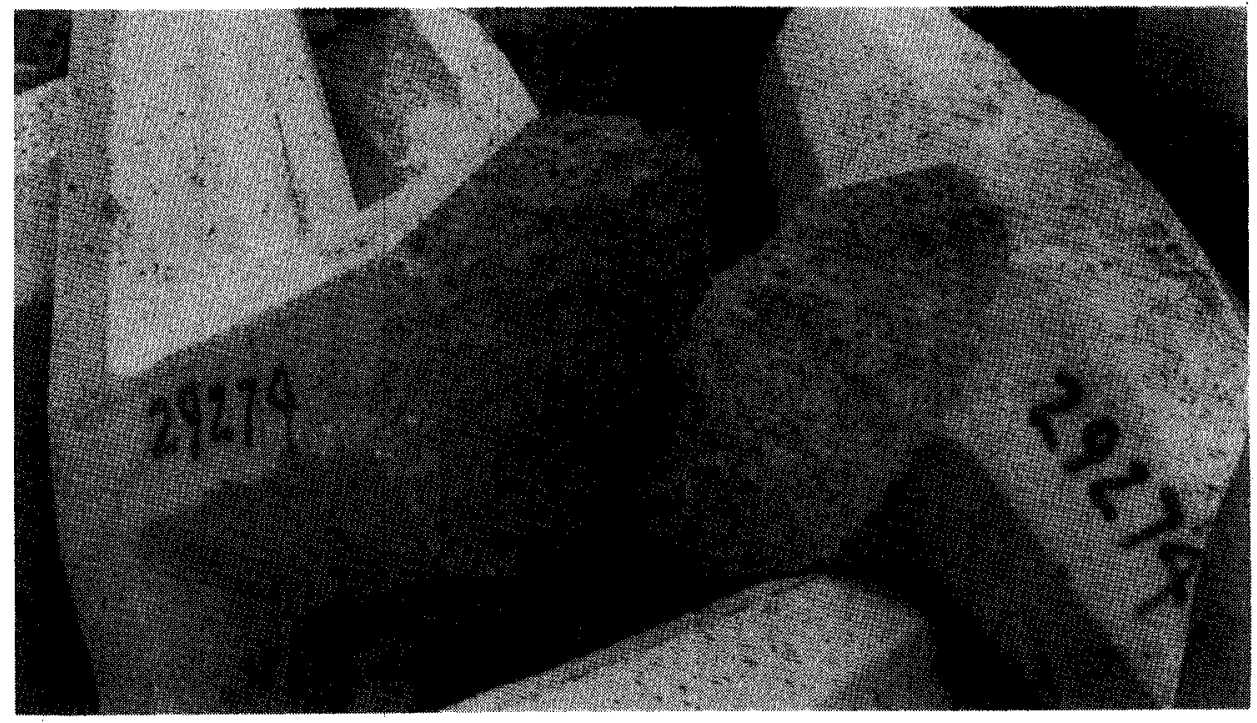

a. Angled stem break

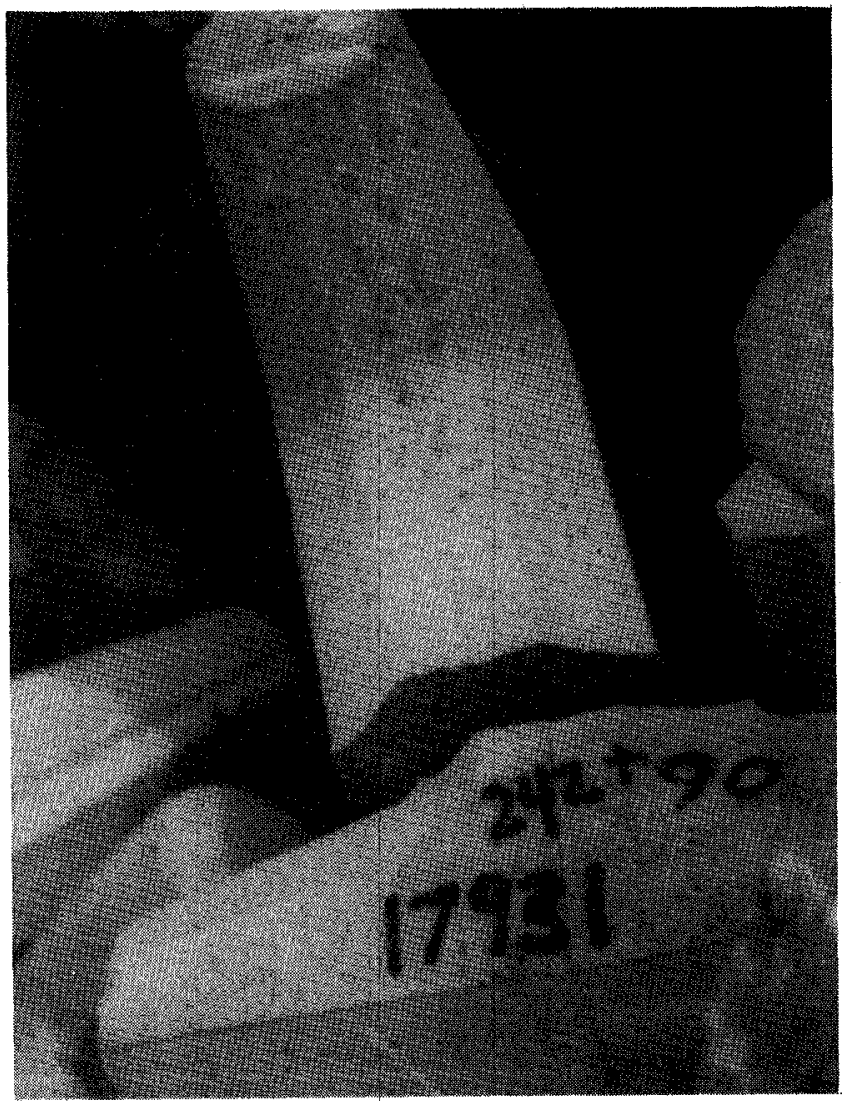

b. Straight stem break

Figure 22. Dolosse with straight and angled stem breaks 


\section{Aerial photography}

Aerial photographs were useful in evaluating both zone and unit changes in the dolos armor cover during the monitoring period. They aided in identifying areas where new dolosse were needed and where individual dolosse were unstable and needed to be repositioned. A 1 in. $=100 \mathrm{ft}$ scale photo of the eastem end of the Cleveland east breakwater, which shows the severity of ice coverage on the lakeside of the structure (Figure 23), was taken in March 1984. Photo enlargements ( 1 in. $=10 \mathrm{ft}$ ) were directly compared (using a light table) to document individual dolos and zone movement.

Evaluation of aerial photographs before and after the April 1982 storm allowed mapping of damage zones and provided the basis for the repair plan. Damage at the head section and movement of units along the trunk were readily identifiable. Also, in the fall of 1982, maintenance requirements of the dolosse along the breakwater trunk were identified using aerial photograph enlargements to determine which dolosse needed to be repositioned. About 60 units were identified and subsequently moved from unstable positions on the crest or harbor side of the structure and keyed back into the lakeside slope. An aerial photo of a portion of breakwater immediately west of the rehabilitated section revealed a breach in the structure and was valuable in developing maintenance plans.

A direct comparison of the October 1981 and September 1985 aerial photograph enlargements was completed by overlaying the images and matching individual dolosse. This comparison yielded the following observations:

a. Most dolos movement along the trunk was between stations $230+00$ and $238+00$, which is the west end of the rehabilitated section.

$b$. The majority of the dolosse that were on the breakwater crest in October 1981 were not present in September 1985 (note: approximately 60 were placed back on the lake slope in October 1982), and a few new dolosse had moved onto the crest. Some dolosse which had moved onto the crest appeared to have keyed into fissures in the stone crest.

c. A comparison of the repaired head section between November 1982 and September 1985 revealed no significant armor unit movement.

Although the aerial photography was a useful monitoring tool, there were a few drawbacks. This type elevation determination required laborious visual image comparison, which can be quite time-consuming. Direct overlay comparison of the enlargement on a light table requires continuous shifting of the images. In spite of target controls, exact scale duplication to the enlargements was not possible, and the enlargement scale may vary across the image. In addition, even though only the center 60 percent of each photo image was enlarged, there was still observable parallax effect, which distorted the apparent positions of the dolosse along the edge of each enlargement. Closer 


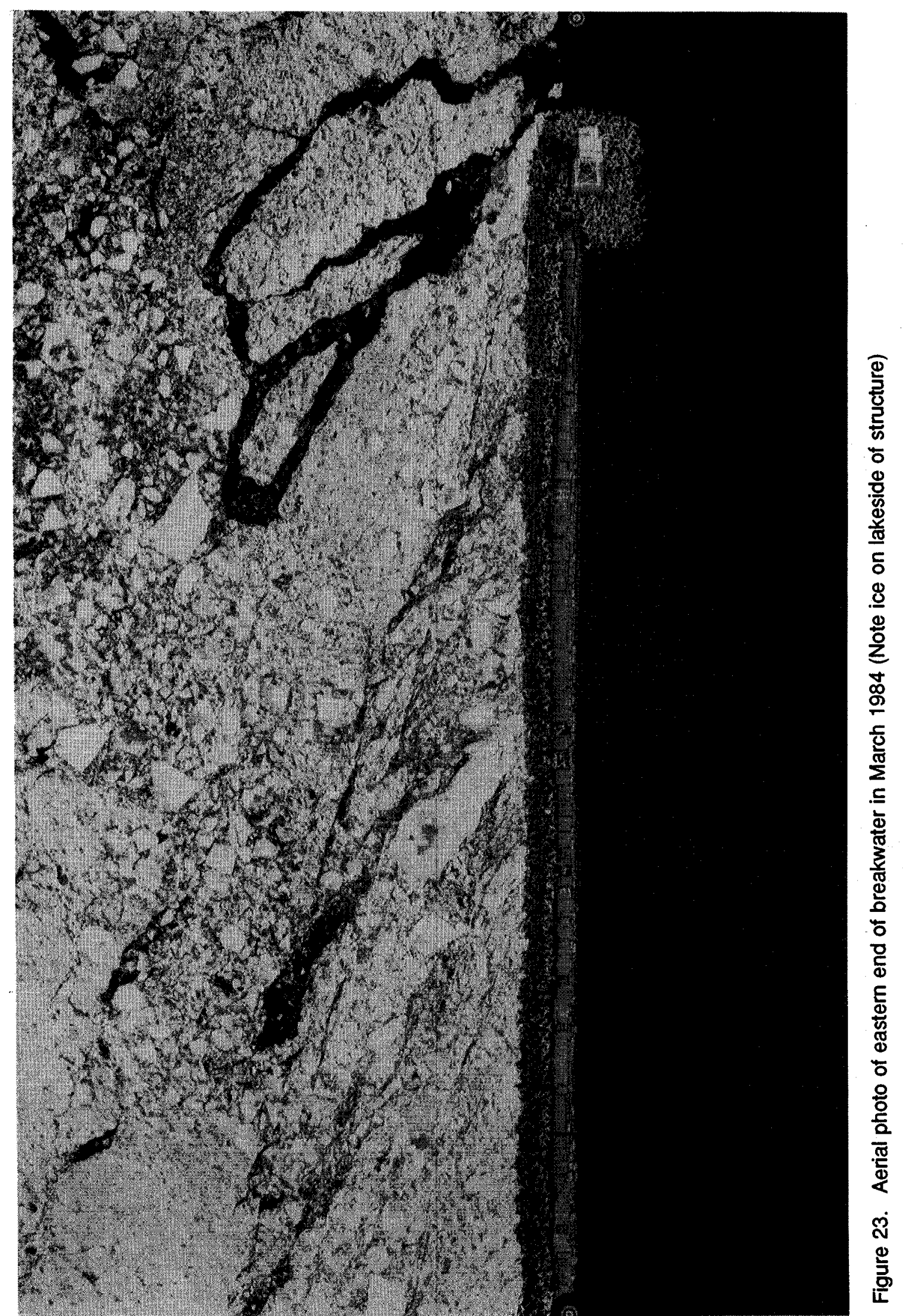


spacing of control points, at least every $200 \mathrm{ft}$, would have ensured more accurate scale enlargement. The targets used at Cleveland were 300 to $900 \mathrm{ft}$ apart. Documentation of crest dolosse was possible under all conditions, but changes in water level hindered the use of the aerials for charting movement at or near the waterline. Finally, although each flight was taken when the sun was toward its apex (between 10:00 am and 2:00 pm), different times of year caused different shadow lengths and orientations, masking the apparent dolosse positioning.

\section{Wave and water levels}

Wave data obtained were analyzed in terms of significant wave height $\left(\mathrm{H}_{8}\right)$ and spectral peak period (T). Figure 24 illustrates examples of wave energy distribution as a function of frequency for wave data obtained both inside and outside the harbor on 17 August 1981. The lakeside waves were always higher than those on the harbor side. Approximately 93 percent of the lakeside waves were less than $3 \mathrm{ft}$, and 6 percent were in the 3- to 6 -ft range. Less than 1 percent exceeded $6 \mathrm{ft}$, and the maximum monitored significant wave height was $7.4 \mathrm{ft}$. For the harbor-side gage, significant wave heights were generally less than $1 \mathrm{ft}$. Only 0.2 percent of the data exceeded $2 \mathrm{ft}$ with a maximum height of $2.4 \mathrm{ft}$. Less than 8 percent of the data were in the range of 1 to $2 \mathrm{ft}$. The peak wave period ranged from 3 to $7 \mathrm{sec}$, with a majority in the 3- to 4-sec range. Wave periods outside the harbor were comparable with the harbor-side data. It should be noted that these wave characteristics do not cover winter conditions, nor were the gages in place during the April 1982 storm.

It was estimated that wave overtopping would occur only when the significant wave heights outside the harbor exceeded the height of the breakwater freeboard (which ranged from 6.3 to $7.8 \mathrm{ft}$ during the monitoring period). By comparing wave height ratios of wave heights greater than $6 \mathrm{ft}$ to those of less than $6 \mathrm{ft}$, it was. noted that wave overtopping was not significant during the monitoring period.

Wave transmission data were obtained during the monitoring period. A typical plot of $\mathrm{H}_{8}$ outside the harbor versus $\mathrm{H}_{8}$ inside the harbor is shown in Figure 25. These data were obtained during storm activity that occurred between 27-29 April 1982. As wind direction shifted from west to east, it was noted that more wave energy was transmitted into the harbor through the entrance. The harbor-side gage recorded larger values as waves diffracted around the breakwater head and, possibly, some waves reflected from the shoreline or structures within the harbor. Conversely, the wave height ratio decreased as winds and waves shifted from east to west. These data suggest that the diffraction process at the head of the east breakwater contributed wave energy to the harbor-side wave gage. 


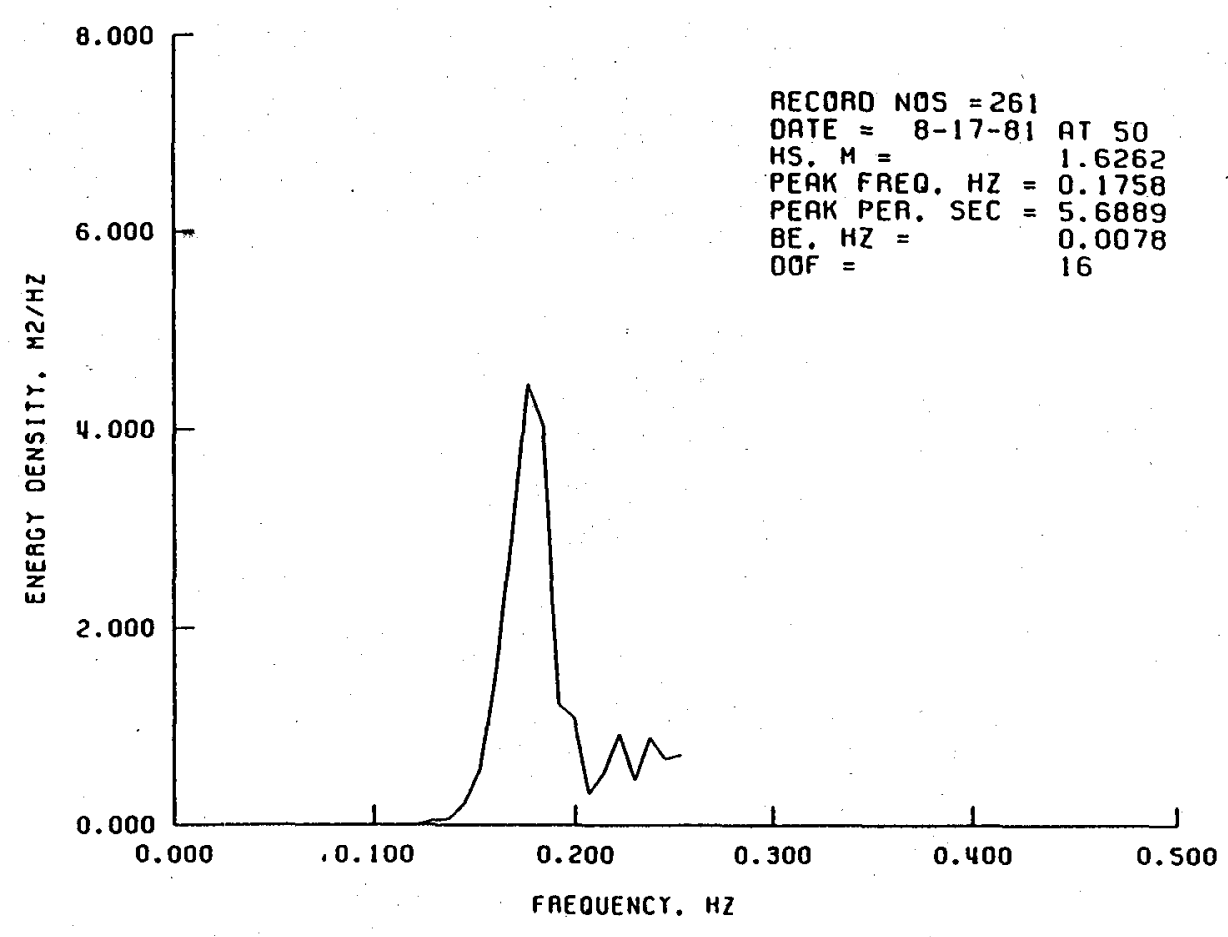

a. Wave energy spectrum from lakeside gage

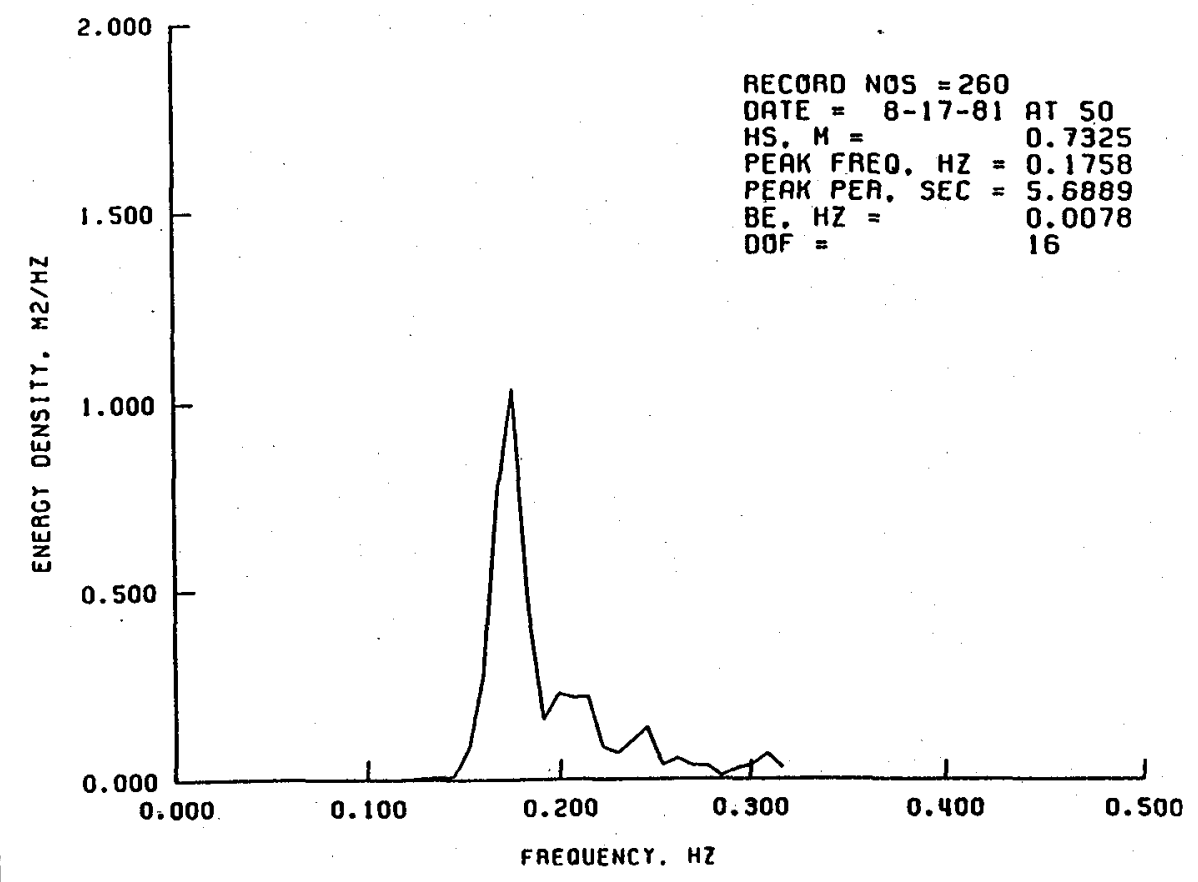

b. Wave energy spectrum from harbor-side gage

Figure 24. Example of wave energy spectra, 17 August 1981 


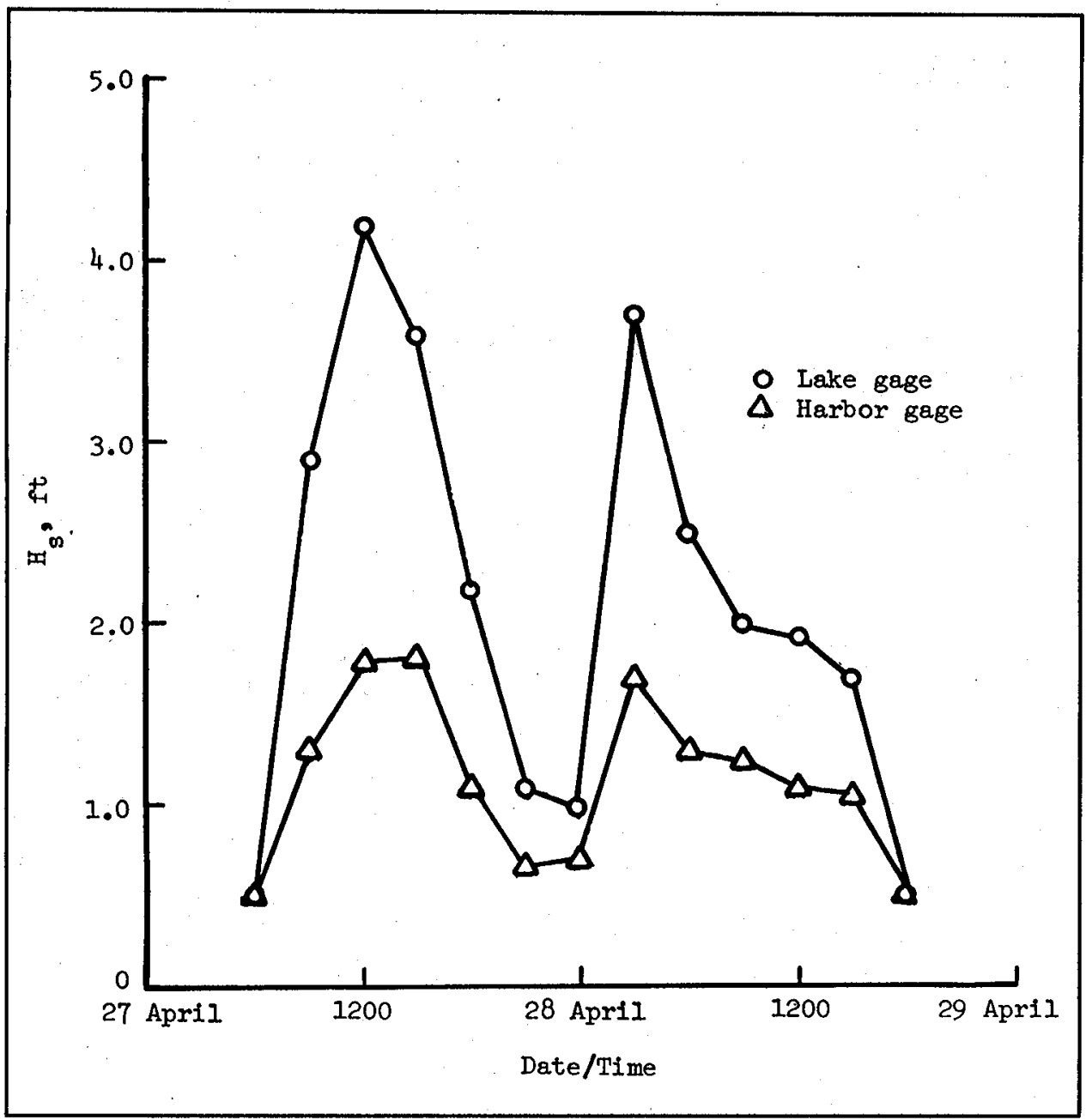

Figure 25. Significant wave heights inside and outside the harbor for the period 27-29 April 1982

Lake levels were monitored continuously during the monitoring period. Still-water levels generally ranged between +2 and $+5 \mathrm{ft}$ lwd during the period 1982-1985; however, the effect of short-term lake level change was demonstrated by the April 1982 storm during which the daily mean was +4.48 1wd, but the instantaneous level was +6.14 lwd. Lake levels occurring during periods when wave conditions were being monitored ranged from about +2.5 to $+4 \mathrm{ft}$ lwd. Monthly mean lake levels over the monitoring period are presented in Figure 26 as well as the number of broken dolosse per survey. It appears that there is no correlation between lake levels and the amount of armor unit breakage, though the water level may affect the location of breakage on the breakwater. Increase in water level during storm conditions may result in damage higher up on the structure and explain dolos breakage near the structure's crest. Also, lake levels at the time of broken dolos surveys will affect the number of armor units visible to the survey team. 


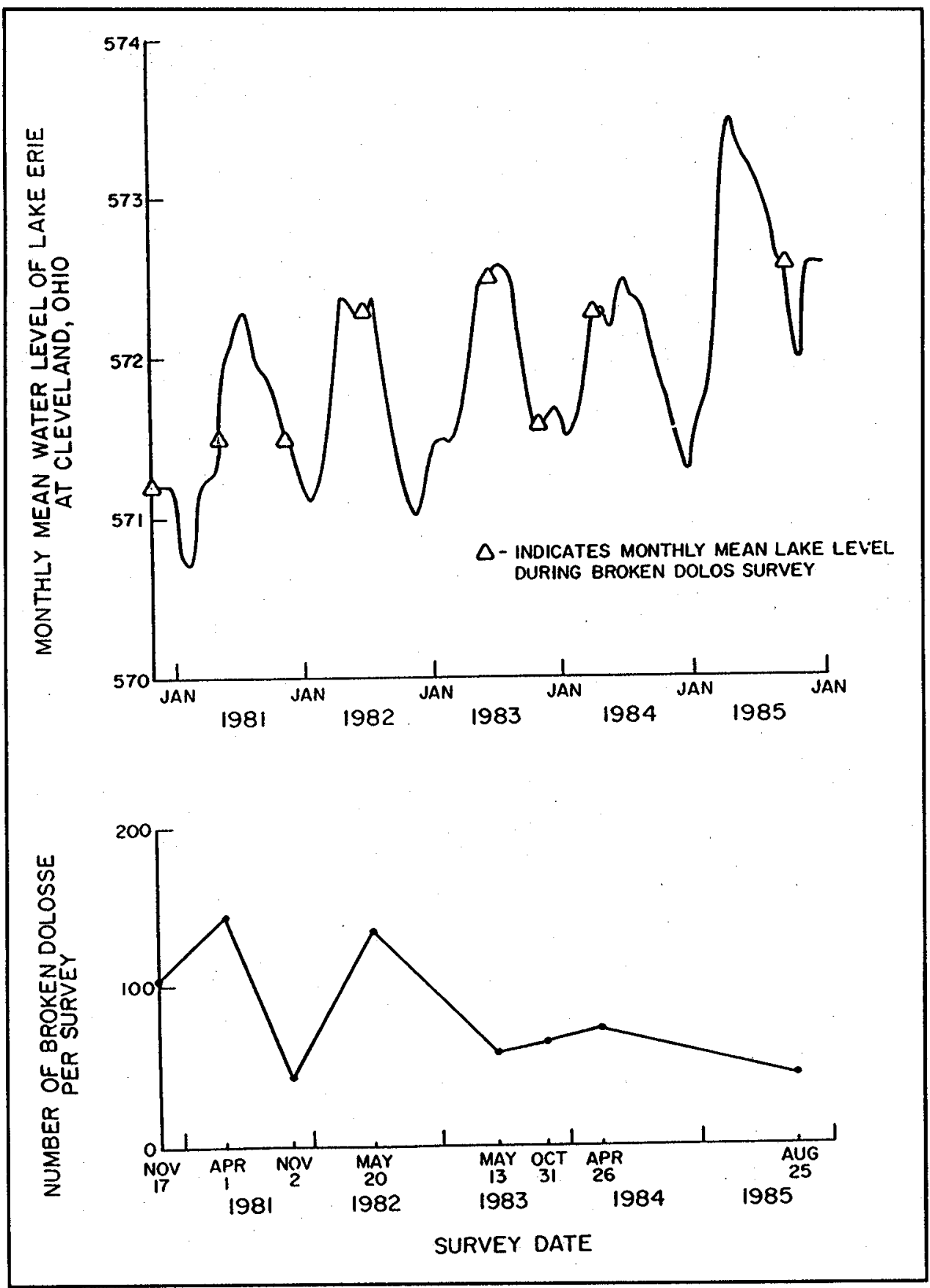

Figure 26. Monthly mean lake level versus number of newly broken dolosse per survey

\section{Side-scan sonar and diving inspectlons}

The side-scan sonar portion of the monitoring program was intended to document changes in the underwater condition of the dolos cover. During the first survey it became apparent that side-scan sonar could only be used as a 
means of obtaining a qualitative record of the slope and toe characteristics of the structure. A dolos cover has certain characteristics such as random placement, high unit relief with small reflective surface, and high void-to-unit ratio which make it difficult to identify individual units and monitor their condition. Lessons learned during the initial survey were used to improve subsequent surveys. For example, a larger boat was used, a short range electronic positioning system was utilized, and operational techniques were well-documented to ensure duplication in future surveys. The rehabilitated dolos-covered breakwater was scanned at least twice during each survey to determine the repeatability of the imagery. Although the individual dolosse are too small to be identified within the structure slope, the structure toe and changes in the slope were distinguishable. A typical side-scan sonar image of the dolos head section of the east breakwater is shown in Figure 27. Just to the right of arrow A at the waterline, an indentation shows where dolosse were lost. The dashed line depicts the dolos toe and the exposed underlayer stone berm. The right side of Figure 27 (arrow B) shows an area where the dolos toe is excessively steep and that some units have been lost down the slope. Many of the lessons learned during the experimentation have been used to improve subsequent studies at other sites (Clausner and Pope 1988).

The initial dive inspection confirmed several interpretations about the dolos cover that were made based on the side-scan records. Additionally, the divers added some site-specific observations. The dolos slope was found to be somewhat irregular and the cover-layer thickness varied. Occasionally the cover layer would be missing, exposing the underlayer, while in other areas, dolosse were stacked three or four units high. The dolos toe in many places was steep with perched units above the general slope and a poorly defined supporting underlayer berm. The steep toe and irregular slope also were present in the first two sets of side-scan sonar records, suggesting that these characteristics were the result of initial underwater placement. The initial diving survey revealed that broken dolosse were scattered and generally appeared to be the result of original placement or to be displaced fragments from above-water breakage.

The 1984 side-scan sonar record was used to identify sections that appeared to have some unique aspects. The divers then targeted their inspections to these areas. A section of the trunk identified during the survey suggested the presence of a large depression in the cover about halfway down the structure slope. The diving inspection confirmed that there was an 8- to 10-ft-wide area with no dolos cover. Dolosse appeared to have slipped and rolled over portions of the underlayer, landing on top of the bedding stone berm. Underwater dolosse at the head section and the transition zone between the head and the trunk were surveyed. In the transition, the underlayer toe was very wide and steeply terraced. The dolos toe in this area was very steep, and approximately 25 broken armor units were observed in this section. Although the breakage was random, some movement and instability throughout the dolos cover in the transition zone was observed. The head section had a very steep cliff of dolosse at the toe and some loss downslope of the units placed in 1982. In general, the underwater condition of the head section included skimpy dolos 


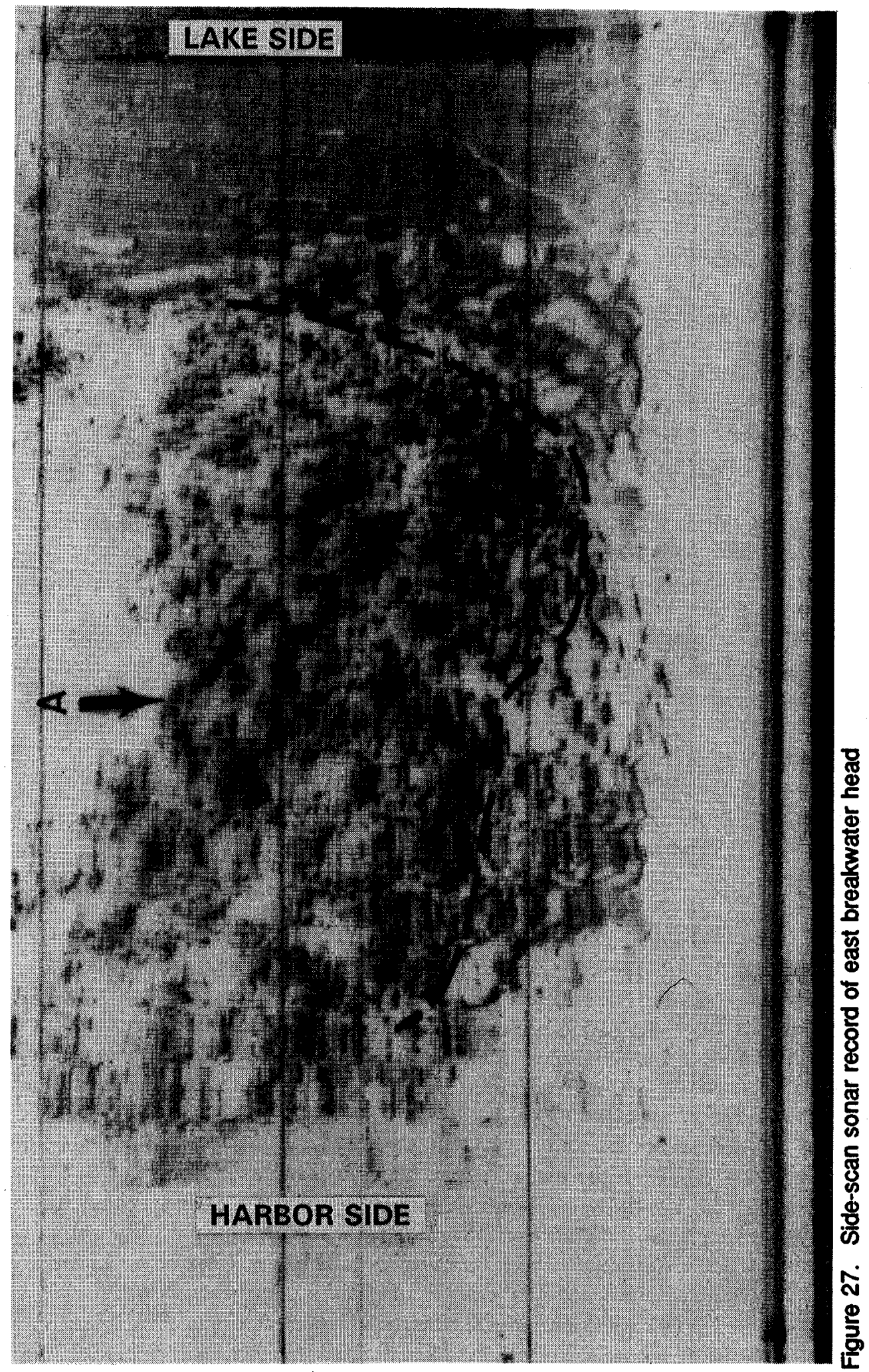


cover near the toe, numerous "hangers," more breakage near the waterline, and scattered broken segments from above the water zone.

The results of the side-scan sonar surveys and diving inspection reveal that the underwater condition of the dolos cover has several flaws due to initial placement. Of primary concern are "holes" in the armor cover and areas where the dolos toe is perched. The side-scan sonar records reveal significant variation in the condition of the structure toe throughout the 4,400-ft length of rehabilitation. There are areas with little or no underlayer berm and other areas where the toe of the dolos cover is very steep. The underwater portion of the trunk did not appear to be very dynamic over the monitoring period. However, new breakage and movement observed during the last survey suggest that the head section and transition dolos cover are still dynamic and are experiencing progressive deterioration. 


\section{Related Studies and Post-Monitoring Activity}

\section{Maintenance Study}

Damages to the head of the east breakwater during the April 1982 storm highlighted the need to develop a maintenance plan. In 1983, an analytical study was performed by the Buffalo District to reassess the existing dolos cover design (based on monitoring data obtained and new studies reported in more recent literature), compare the design criteria for a dolos armored structure to a stone armored structure, and develop a recommended maintenance plan.

The study resulted in several conclusions which are noted below:

a. The hindsight redesign for the Cleveland east breakwater would incorporate a number of improvements, including larger-sized units, minor reinforcement (particularly for dolosse placed in the active wave zone and on the head section), the use of a more standard concrete mix design, and physical model testing.

b. Dolosse (or other types of precast armor units) are a very competitive option where the design requires large quantities of 10-ton and greater size quarrystone.

c. Average annual damages were computed for a quarry stone and a dolos structure using the SPM (1977) damage table and a statistical analysis of the average annual chance that the design wave would be exceeded. The percentage of average annual damage to a properly designed dolos cover was found to be comparable to the damage expected with a quarry stone cover (i.e., 1.4 percent for quarry stone and 1.45 percent for dolos). This analysis considered only damage due to displacement of the armor cover due to wave activity exceeding the design wave and did not address the issue of degraded dolos unit integrity or breakage.

d. The main purpose of the dolos maintenance program was to rebuild areas that have lost grade, because of breakage, dolos loss, and 
settlement of the dolos cover, and to replace the armor cover over a limited area of failure.

e. A long-term maintenance program for the Cleveland east breakwater was computed to require 200 to $\mathbf{4 0 0}$ dolosse per year. For the immediate future, the maintenance program was projected as requiring much lower quantities (say, 50 dolosse per year).

f. Several improvements were recommended for the maintenance dolos including the use of a 4,000-psi concrete mix instead of the 6,000-psi mix used during original construction, the use of steel rebar reinforcement concentrated in the fluke-stem joint, and an increase in dolos size from 2 tons to $2-1 / 2$ tons.

\section{Two-Dimensional Model Study}

The 2-ton dolos cover on the eastern end of the Cleveland east breakwater was designed according to state-of-the-art criteria available at the time, and based on procedures in the SPM (1977). Monitoring efforts indicate that the units appear to be undersized, as evidenced by the breakage and displacement that have occurred. This may partially be a result of excessive wave reflection off the smooth surface of the original structure's laid-up stone armor layer and the vertical lighthouse base at the breakwater head. A proposal to rehabilitate an additional 3,300 $\mathrm{ft}$ of the east breakwater was initiated in 1984. To determine the optimum armor to be used in the future at Cleveland, a twodimensional model investigation at WES was authorized and funded.

The model investigation (Markle and Dubose 1985) was conducted in a concrete flume using an undistorted linear scale of 1:28.5. The facility was equipped with a vertical-motion wave generator capable of producing monochromatic waves with the required periods and heights. A typical cross section of the original laid-up stone structure was reproduced and the lakeside slope was covered with two layers of randomly placed dolosse or armor stone, depending on the plan being tested. The purposes of the model study were to:

a. Evaluate the stability of 4-ton dolosse when exposed to design wave and still-water level conditions.

b. Determine the degree of breakwater damage that could occur on the 4-ton dolos design for a storm condition that exceeds the design wave condition.

c. Determine maximum nonbreaking wave heights that the existing 2-ton dolos design and the proposed 4-ton dolos and 9- to 20-ton armor-stone designs could withstand. 
Tests were conducted using a design still-water level (swl) of $+4.9 \mathrm{ft}$ and wave periods of 7,8 , and $9 \mathrm{sec}$ with a 13.4-ft design wave height. Wave heights of $10.5,11,12$, and $15 \mathrm{ft}$ also were tested.

The 4-ton dolos cover appeared to be stable, sustaining only minor crown damage under 12-ft wave conditions. Testing of the 4-ton dolos under design conditions (13.4-ft waves), however, indicated that this alternative has a high potential to sustain damage on the crown and upper slope. Thus, the 4-ton dolos design was considered to be marginally acceptable and may require significant maintenance if exposed to design conditions. The 4-ton dolos proved to be inadequate for 15 - $\mathrm{ft}$ wave conditions with the structure accruing extensive damage to the dolos on the crown and upper lakeside slope. A view of the 4-ton dolos test section in the two-dimensional model is shown in Figure 28.

Following completion of the 4-ton dolos tests, the Buffalo District requested tests to determine the stable design wave height for the existing 2-ton dolos. These units could not be reproduced exactly in the model without changing the existing model scale and recalibrating the test facility; therefore, a 2.3-ton dolos was selected. This provided the most cost-effective approach, as well as the information required. Wave heights of $10.5 \mathrm{ft}$ caused only minor displacement and in-place rocking; however, 11 -ft wave heights produced significant amounts and degrees of in-place rocking of the dolosse on the crown and upper lakeside slope. It was concluded that the 2.3-ton dolos appears to be a stable design, and should sustain only minor crown damage, for 10.5 - $\mathrm{ft}$ waves with a +4.9-ft swl.

The final test sequence was conducted for 9- to 20-ton armor stone. Wave heights below $13.4 \mathrm{ft}$ resulted in only minor rocking and very slight in-place reorientation of a few armor stones on the crown and upper lakeside slope, while 13.4-ft waves caused some armor stone displacement in these areas. Further testing concluded that the 9- to 20-ton armor stone appeared to be a stable design and should sustain only minor damage in an area extending from swl to the crown when exposed to the design waves (13.4 ft) and design swl $(+4.9 \mathrm{ft})$.

In summary, the 9- to 20-ton armor cover exhibited the greatest stability of the plans tested under design conditions, and the 4-ton dolos was found to be marginally acceptable under design conditions. The 2.3-ton dolos was determined to be stable against a maximum wave height up to $10.5 \cdot \mathrm{ft}$ with $\mathrm{a}+4.9-\mathrm{ft}$ swl.

\section{Post-Monitoring Rehabilitation}

The winter of 1986-87, subsequent to the conclusion of the monitoring program, was characterized by higher than average lake levels, and several storms occurred during the period. In the spring of 1987 , it was noted that 


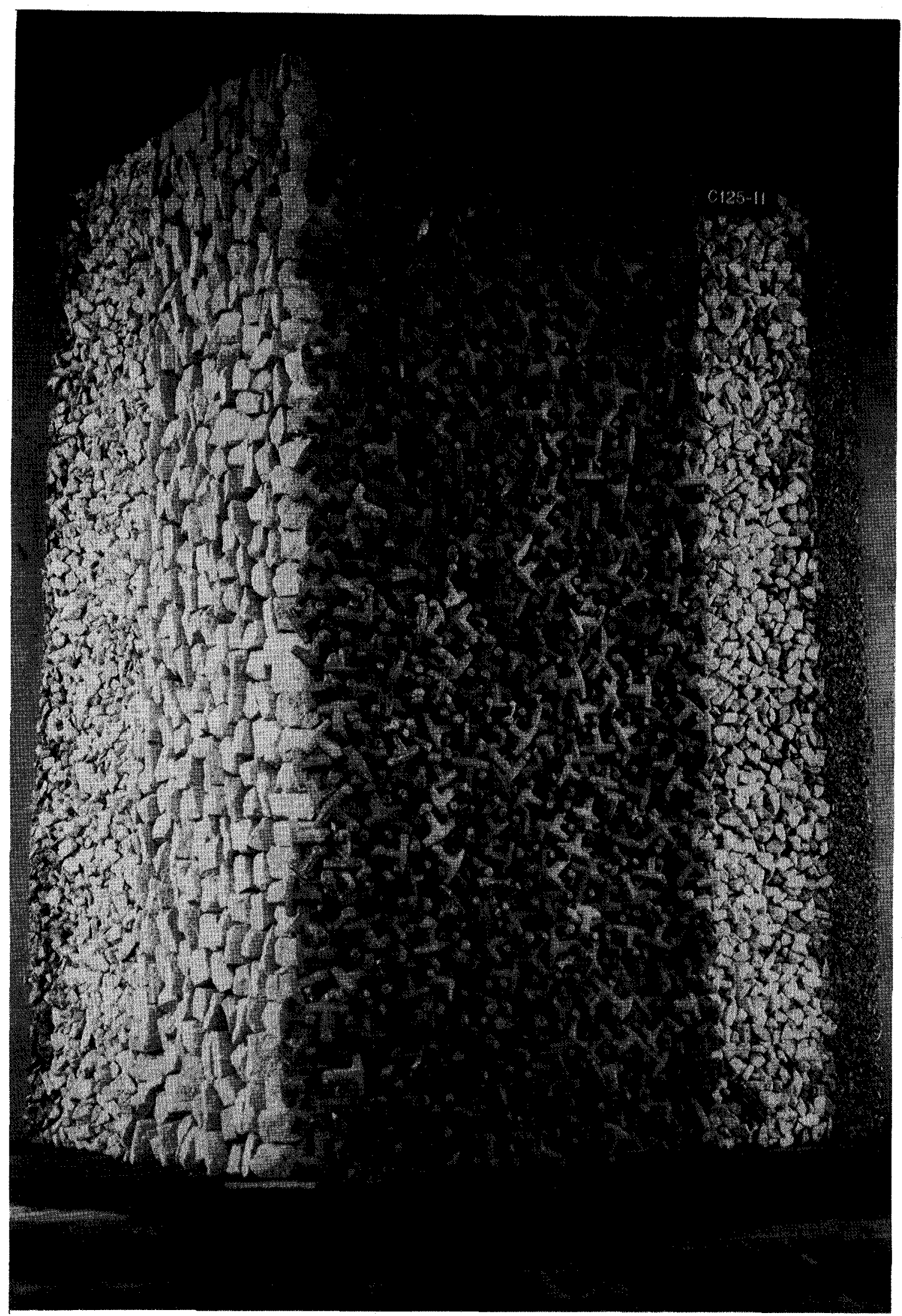

Figure 28. Overhead view of 4-ton dolos section in two-dimensional model 
most of the 2-ton dolosse around the head of the lighthouse on the eastern end of the structure were missing (Figure 29). The damage was evaluated and in May 1987, 234 dolos armor units were placed around the head (Figure 30). These were 4-ton units as opposed to the 2-ton units previously used. Several 4-ton dolosse were also placed in low areas along the trunk to bring it back to the correct elevation. The 4-ton units appear to have remained stable around the head of the east breakwater since the 1987 rehabilitation.

It is unclear as to the time and cause of the 1986-87 failure. Immediately west of Cleveland Harbor, it was noted that a recently completed fishing pier at Edgewater Park also was destroyed during February 1987 by wave action. Review of hindcast data (Driver, Reinhard, and Hubertz 1991) indicated that at the peak of a storm on 9 February 1987, a deepwater wave height of $9.5 \mathrm{ft}$ with a 7.1-sec period occurred from the north. Deepwater wave heights ranging from 8 to $9.5 \mathrm{ft}$ occurred for about $10 \mathrm{hr}$. A slightly more severe storm from the northeast, but with a much longer duration, occurred during early April 1987 (Driver, Reinhard, and Hubertz 1991). This storm had a deepwater wave height of $10.2 \mathrm{ft}$ with a period of $7.7 \mathrm{sec}$. Wave heights greater than $8 \mathrm{ft}$ occurred for over $24 \mathrm{hr}$. Another April storm yielded 8-ft and greater waves from the north northeast for about $12 \mathrm{hr}$, with deepwater heights of $11.2 \mathrm{ft}$ and periods of $8.3 \mathrm{sec}$.

These 1987 storms were not as severe as the April 1982 event, but caused significantly more damage. Dive inspections in the spring of 1987 revealed a significant number of dolos fragments scattered over the underwater slope.

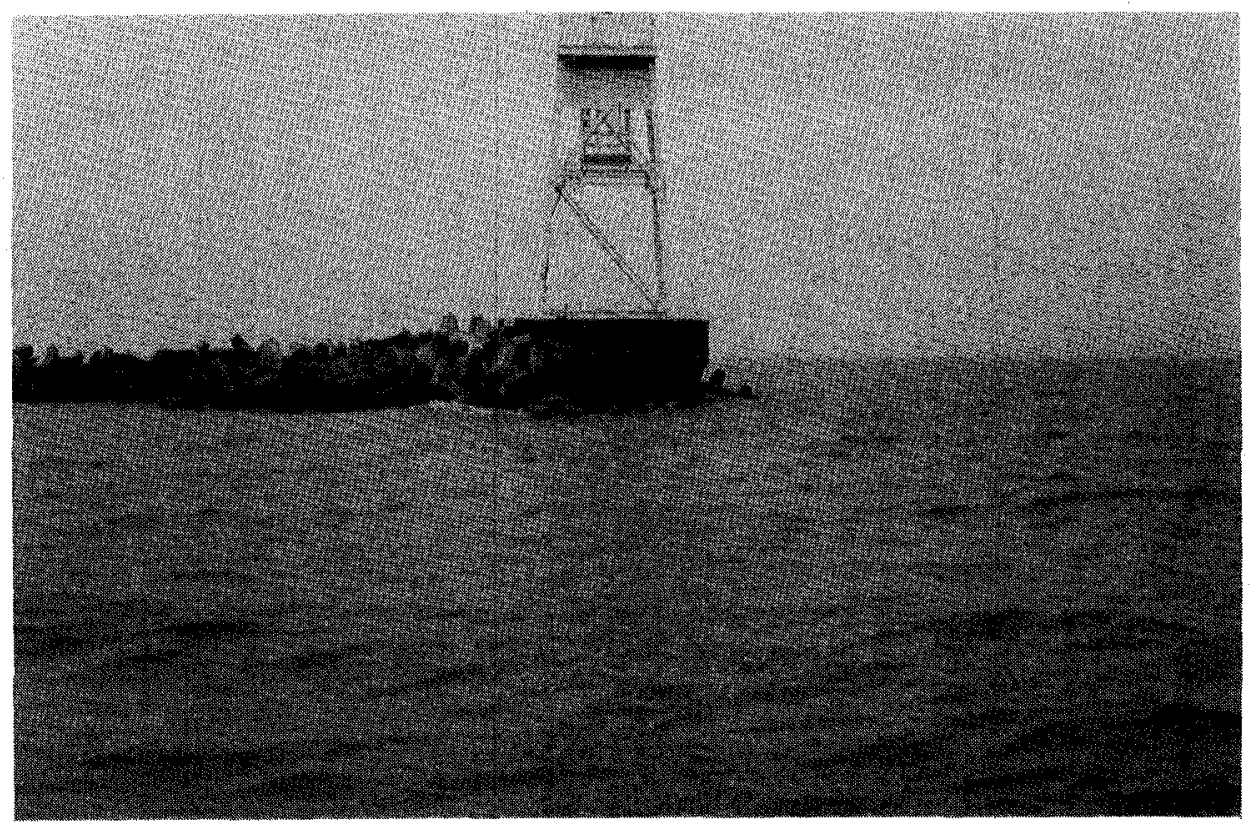

Figure 29. View of head of east breakwater after the 1986-87 winter. Note most the dolos cover is missing 


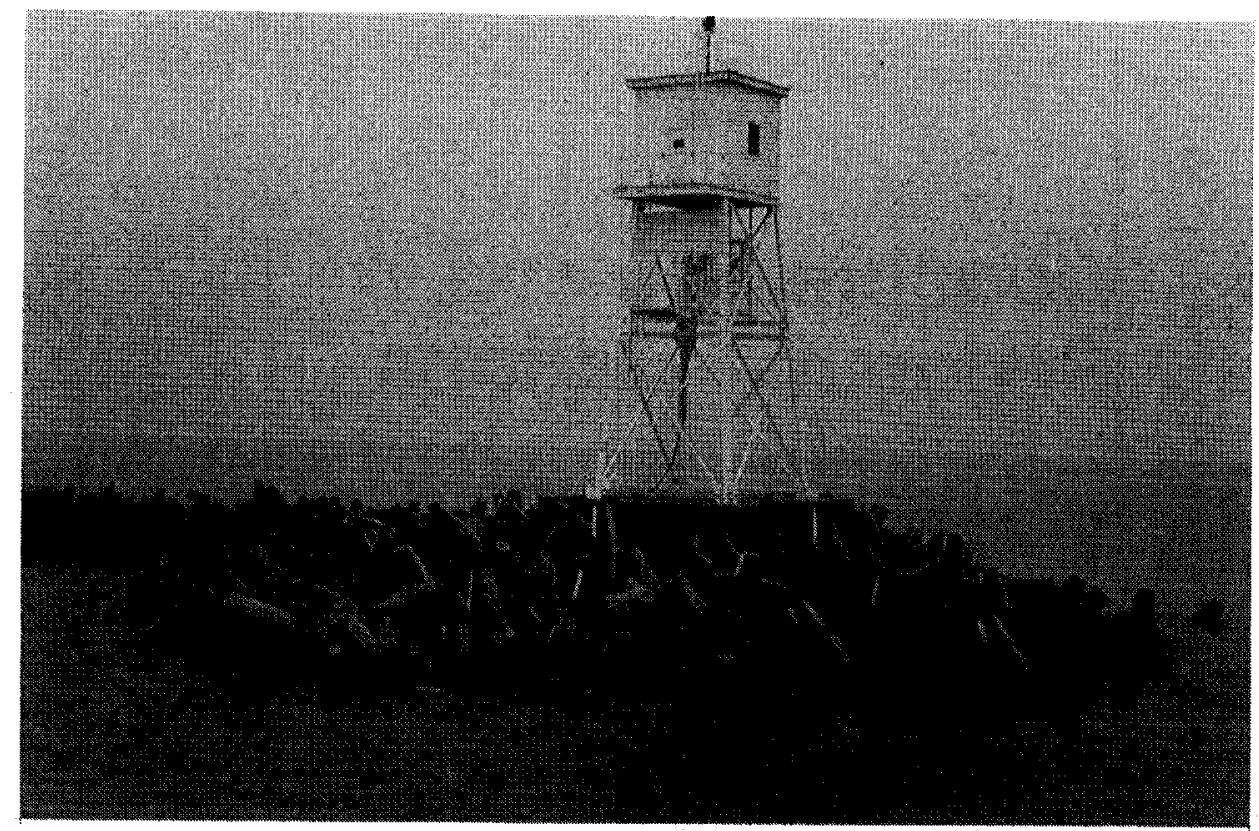

Figure 30. View of 4-ton dolos units placed around head of structure in May 1987

These findings suggest that the duration of the storm may be just as important as the incident wave heights. It is conjectured that prolonged rocking of the units may have caused the failure at the east breakwater head during 1987. This experience may serve as a warning and spawn research for improved design criteria. 


\section{Conclusions and Recommendations}

\section{Conclusions}

Although the 2-ton dolos armor layer has deteriorated over the years, the breakwater continues to provide the required level of shore protection. Maintenance of the dolos cover has been on an as-needed basis. Repairs, including repositioning and/or the installation of additional armor units, are required after major storms.

Wave reflection off the vertical concrete navigation light foundation at the breakwater head appears to contribute to the loss of armor units in that area. Dolos armor units are very porous when a two-layer thickness is used. Wave energy transmits through the dolosse at Cleveland and reflects back upon them, apparently popping them out of place. Additional layers over reflective surfaces may be prudent for highly porous armor units.

As evidenced by significant movement and breakage, the 2-ton dolosse . appear to be underdesigned for the Cleveland east breakwater. The twodimensional model study also indicated that 4-ton armor units (as opposed to 2-ton) would decrease the probability of movement.

During the monitoring period, the 2-ton dolos cover continued to subside and lose elevation. Breakage of armor units also occurred throughout the monitoring period, but the rate of breakage appeared to decrease slightly toward the end of the monitoring period. Most breakage occurred along the waterline in the active wave zone. Little continued breakage was noted below the waterline during diving inspections.

Aerial photography of the dolos cover proved to be a useful tool during the monitoring program in spite of the fact that the photos were not completely rectified. Photos were used to evaluate qualitative changes in the armor cover. This photography served as the basis for planning maintenance and repair of damage zones during the monitoring period. 
Wave gages were not deployed at Cleveland during the winter months because of the concern that they would be lost to ice. Unfortunately, most severe storms during the monitoring period occurred during the winter. The wave data collected, therefore, were not representative of the most severe storm conditions.

Side-scan sonar surveys proved to be a valuable means for obtaining qualitative documentation of the condition of the structure toe and the consistency of the cover layer slope. Combined with diving surveys, the underwater condition of the dolos cover was determined to have several flaws from original construction, including zones of no armor and areas where the toe appears unstable.

\section{Recommendations}

General observations, with respect to dolos usage, were made from the monitoring program results at Cleveland. Since dolos breakage can jeopardize the structure's integrity, dolosse should be designed for "no-rocking" criteria to minimize breakage due to movement. Consideration also should be given to reinforcement of dolosse in the active wave zone for a deepwater structure, since breakage appears to be concentrated in this area. In addition, dolosse should be placed over a stone underlayer rather than against a flat surface to prevent movement caused by wave reflection.

The two-dimensional model study investigation, conducted subsequent to prototype construction, indicated that the dolos cover at Cleveland would be unstable for wave conditions in excess of $10.5 \mathrm{ft}$. When new breakwater cover concepts are being considered, a model investigation, incorporated as part of the design, would help in selecting the optimum cover unit. Proper design will minimize repair and rehabilitation costs during the life of these projects.

Aerial photography targets and dolosse identified for armor unit surveys at Cleveland ranged from 300 to $900 \mathrm{ft}$ apart. More detail would have been useful in rectifying stero pairs. For future monitoring efforts, it is recommended that controls be established to place at least three targets in each photo frame.

Photogrammetry could be an excellent means of mapping armor units above the waterline. The technique used at Cleveland, however, was qualitative. Emphasis should be placed on continued improvement of remote sensing methodology. With proper rectifying of stereo pairs, photogrammetry can be used to quantify armor unit movement in the $x, y$, and $z$ directions at relatively low cost (Gebert and Hemsley 1991).

Side-scan sonar proved to be an excellent qualitative tool at Cleveland Harbor. Side scan should be considered during construction as an alternative to extensive and costly diver surveys, to inspect underwater placement of the structure. Sonar allows the inspection of large structures rapidly and 
economically. Annual records also could aid in identifying potential underwater problem areas as they evolve. 


\section{References}

Bottin, R. R., Jr. (1988a). "Case histories of Corps breakwater and jetty structures; Report 1, South Pacific Division," Technical Report REMR-CO-3, U.S. Army Engineer Waterways Experiment Station, Vicksburg, MS.

(1988b). "Case histories of Corps breakwater and jetty structures, Report 3, North Central Division," Technical Report REMR-CO-3, U.S. Army Engineer Waterways Experiment Station, Vicksburg, MS.

Clausner, J. E., and Pope, J. (1988). "Side-scan sonar applications for evaluating coastal structures," Technical Report CERC-88-16, U.S. Army Engineer Waterways Experiment Station, Vicksburg, MS.

Driver, D. B., Reinhard, R. D., and Hubertz, J. M. (1991). "Hindcast wave information for the Great Lakes: Lake Erie," WIS Report 22, U.S. Army Engineer Waterways Experiment Station, Vicksburg, MS.

Gebert, J. A., and Hemsley, J. M. (1991). "Monitoring of jetty rehabilitation at Manasquan Inlet, New Jersey," Miscellaneous Paper CERC-91-8, U.S. Army Engineer.Waterways Experiment Station, Vicksburg, MS.

Hudson, R. Y. (1974). "Concrete armor units for protection against wave attack," Miscellaneous Paper H-74-2, U.S. Army Engineer Waterways Experiment Station, Vicksburg, MS.

Markle, D. G., and Dubose, W. G. (1985). "Wave stability tests of dolos and stone rehabilitation designs for the east breakwater, Cleveland, Ohio," Technical Report CERC-95-10, U.S. Army Engineer Waterways Experiment Station, Vicksburg, MS.

Merrifield, E. M. (1974). "General discussion of dolos armor units," Frederic R. Harris Consulting Engineers, New York.

Pope, J., and Clark, D. R. (1983). "Monitoring of a dolos armor cover; Cleveland, Ohio." Coastal Structures '83. American Society of Civil Engineers, New York. 
Resio, D. T., and Vincent, C. L. (1976). "Design wave information for the Great Lakes; Report 1, Lake Erie," Technical Report H-76-1, U.S. Army Engineer Waterways Experiment Station, Vicksburg, MS.

Port Sines Investigating Panel. (1982). "Failure of the breakwater at Port Sines, Portugal," ISBN 0-87262-298-3, American Society of Civil Engineers, New York.

U.S. Army Engineer District, Buffalo. (1976). "Cleveland Harbor, Ohio, feasibility report for harbor modification, final feasibility report: Vol 1, main report," Buffalo, NY.

(1979). "East breakwater major rehabilitation, Cleveland Harbor, Ohio," Design Memorandum, Buffalo, NY.

Zwamborn, J. A., and Niekerk, M. (1981). "Survey of dolos structures," CSIR Research Report 385, Coastal Engineering and Hydraulics Division, National Research Institute for Oceanology, Council for Scientific and Industrial Research, Stellenbosch, South Africa. 


\section{REPORT DOCUMENTATION PAGE}

Public reporting burden for this collection of information is estimated to average i hour per response, including the time for reviewing instructions, searching existing data sources. gathering and maintaining the dota needed, and completing and reviewing the collection of information send comments regarding this burden estimate or any other aspect of this Davis Highway, Suite 1204, Aflington, VA 22202-4302, and to the Office of Management and Budget, Paperwork Reduction Project (0704-0188), Washington, DC 20503.

\begin{tabular}{l|l|l} 
1. AGENCY USE OFTY (Leave blank). 2. REPORT DATE & 3. REPORT TYPE ARD DATES COVERED
\end{tabular}

\begin{tabular}{|l|l|l|l} 
& July 1993 \\
\hline
\end{tabular}

4. THEE ANO SUBTMLE

July 1993

5. FUNGING NUMBERS

Monitoring of East Breakwater Rehabilitation at

Cleveland Harbor, Ohio

6. AUTHOR(S)

Joan Pope, Robert R. Bottin, Jr., Darlene Rowen

7. PEAFORMTNE ORGANIZATION NAKYE(S) ANO ADDRESS(ES)

8. PERFORMIIYG ORGANIZATTOO

USAE Waterways Expetiment Station

REPORT NUMBER

Coastal Engineering Research Center

3909 Halls Ferry Road, Vicksburg, MS 39180-6199;

USAED; Buffalo

1776 Niagara St. Buffalo. NY 14207-3199

9. SPONSORTNG / MONTORING AGENCY NATE(S) ANDD ADDRESS(ES)

Miscellaneous Paper

CERC-93-5

10. SPONSORING/MONTORINC AGENCY REPORT NUMAER

U.S. Army Corps of Engineers

Washington, DC 20314-1000

11. SUPPLENENTARY NOTES

Available from National Technical Information Service, 5285 Port Royal Road, Springfield, VA 22161.

128. DISTRIBUTION/AVAILADILITY STATEMENT

126. DISTRESUTION CODE

Approved for public release; distribution is unlimited.

13. ABSTRACT (Moximum 200 words)

Under the Monitoring Completed Coastal Projects Program, an assessment of the performance of rehabilitation of the Cleveland Harbor east breakwater was conducted. Monitoring was performed during the period November 1980 - September 1985. The monitoring program relied heavily upon the use of ground control surveys, aerial photography to monitor above-water dolos movement, periodic inventories of individual armor units for breakage, and side-scan sonar to document underwater conditions. Non-directional prototype wave gages also were used to record the wave climate during the ice-free period at the site. Data on performance of the project, observations noted in the prototype, and results of data collection, as well as conclusions and recommendations based on the monitoring effort, are reported herein.

\begin{tabular}{|c|c|c|c|}
\hline $\begin{array}{l}\text { 14. SUBSECT TERMS } \\
\text { Aerial photography } \\
\text { Armor units } \\
\text { Breakwaters }\end{array}$ & $\begin{array}{l}\text { Cleveland Harbor, Ohio } \\
\text { Dolosse } \\
\text { Model stability tests }\end{array}$ & $\begin{array}{l}\text { Side-scan sonar } \\
\text { Structure stability } \\
\text { Waves }\end{array}$ & $\begin{array}{l}\text { 15. NUMEER OF PAGES } \\
\text { S6 } \\
\text { 16. PRICE COOE }\end{array}$ \\
\hline $\begin{array}{l}\text { 17. SECURITY CLASSIFICATION } \\
\text { OF REPORT }\end{array}$ & $\begin{array}{l}\text { 18. SECURITY CLASSIFICATION } \\
\text { OF THIS PAGE }\end{array}$ & $\begin{array}{l}\text { 19. SECURITY CLASSIFICATION } \\
\text { OF ABSTRACT }\end{array}$ & 20. LIMITATION OF ABSTRACT \\
\hline UNCLASSIFIED & UNCLASSIFIED & & \\
\hline
\end{tabular}

